DOI 10.4467/2543733XSSB.17.031.8329

PAWEŁ PŁANETA

Uniwersytet Jagielloński

\title{
BOŚNIA I HERCEGOWINA NA ROZDROŻU. ODBUDOWA MUZUŁMAŃSKIEJ TOŻSAMOŚCI CZY ISLAMIZACJA KRAJU?
}

Słowa kluczowe: Bośnia i Hercegowina, tożsamość islamska, terroryzm, stosunki międzynarodowe

\section{Wstęp}

Jesienią 2010 roku nagłówki prasy światowej alarmowały, że radykalny islam wykorzystuje bałkańską biedę, aby przejąć władzę. Istotnie, blisko dekadę po zmianach terytorialnych na Bałkanach, a także po zamachach terrorystycznych w USA zaczęto dostrzegać rosnące wpływy fundamentalizmu islamskiego w regionie. Ogromne sumy pieniędzy, płynące szerokim strumieniem z Arabii Saudyjskiej i innych państw muzułmańskich, oraz działalność wahhabickich ${ }^{1}$ duchownych okazały się skutecznym narzędziem wpływu na młodych ludzi, którzy od Bośni i Hercegowiny po Kosowo zmagają się z bezrobociem, korupcją i brakiem perspektyw. Pesymiści twierdzili wówczas, iż wiele wskazuje na to, że Bośnia wkrótce stanie się Iranem Europy².

1 Wahhabizm (arab. لو هابية, al-Wahhābija) jako nurt religijny postulujący powrót do pierwotnego islamu narodził się w wieku XVIII. Jest to ruch reformatorski i religijno-polityczny w łonie islamu sunnickiego, powstały w XVIII wieku na terenie Arabii. Ma on charakter „ultrakonserwatywny”, „surowy”, „fundamentalistyczny”. W następnym stuleciu pojawił się salafizm (arab. سلفية-salafijja od: salaf - ,przodkowie”), czyli ruch reformatorski i religijno-polityczny w łonie islamu sunnickiego, postulujący „odrodzenie islamu” poprzez „powrót do jego pierwotnych źródeł”, tzn. „religii przodków”. Z salafizmu wywodzi się XX-wieczny sunnicki fundamentalizm islamski. Por. J. D an e k ki: Podstawowe wiadomości o islamie. [T.] 1. Warszawa: „Dialog”, 1997, s. 53-54 oraz s. 211.

2 S. Pog gi o li, Radical Islam Uses Balkan Poor To Wield Influence, http://www.npr.org/templates/story/ story.php?storyId=130801242

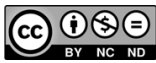


Dwadzieścia lat od zakończenia wojny w Bośni i Hercegowinie ${ }^{3}$ miejscowi muzułmanie zaczęli głośno wyrażać rozczarowanie demokracją. International Crisis Group ${ }^{4}$ opublikowała raport, w którym nazwano mariaż nacjonalizmu i islamizmu ${ }^{5} \mathrm{w}$ Bośni ,niebezpiecznym tangiem". Autorzy raportu podkreślają, że ruchy wahhabickie są wprawdzie małe i podzielone, ale sytuacja w kraju sprzyja ich rozwojowi ${ }^{6}$, gdyż islamiści skutecznie wyzyskują społeczną frustrację. W odróżnieniu od Chorwatów czy Serbów, bośniaccy Muzułmanie nie otrzymują wsparcia gospodarczego, politycznego, ani nawet duchowego ze strony krajów ościennych, dlatego też czują się osamotnieni w dążeniach do zachowania odrębnej tożsamości, a coraz większa liczba mieszkańców kraju zaczęła uważać, że to nie demokracja, a ustrój islamski oparty na prawie szariatu może stanowić lekarstwo na trudności Boszniaków?

Nie powinien zatem nikogo dziwić fakt, że kilkanaście miesięcy później - w 2011 roku - kilkanaście osób zostało zatrzymanych na terenie Serbii w związku z atakiem na ambasadę amerykańską w Sarajewie, przeprowadzonym przez wyznawców ortodoksyjnej odmiany islamu. Co więcej, na początku 2015 roku nad bośniacką wioską Gornja Maoča załopotała flaga ISIS, a w kwietniu tegoż roku rozpoczął się proces Huseina „Bilala” Bosnicia, „bośniackiego salafity” - jak określiły go media - wspierającego tak zwane Państwo Islamskie.

${ }^{3}$ Por. D. Giba s-Krzak, Bośnia i Hercegowina - upadek idei państwa multietnicznego na przełomie XX i XXI w. Zarys problemu, [w:] Bośnia i Hercegowina 15 lat po Dayton. Przeszłość - teraźniejszość - perspekty$w y$, red. P. Chmielewski, S. L. Szczesio, Łódź 2011, s. 283-304, a także D. G i b a s-K r z a k, Terroryzm islamski na Bałkanach Zachodnich jako konsekwencja rozpadu Jugosławii w świetle badań naukowców bałkańskich oraz zachodnich. Zarys problemu, [w:] Bałkany Zachodnie miedzy przeszłością a przyszłościa, red. P. Chmielewski, S. L. Szczesio, Łódź 2013, s. 277-298.

${ }^{4}$ Międzynarodowa organizacja pozarządowa z siedzibą w Brukseli, działająca na rzecz rozwiązywania konfliktów na świecie.

5 Termin ,islamizm” oznacza totalizujący islam polityczny - tj. odnoszący się każdego aspektu ludzkiej egzystencji, a zwłaszcza kwestii politycznych, społecznych, ekonomicznych. Wbrew rozpowszechnionej opinii islamizm nie jest formą islamu tradycyjnego. Odwoływanie się do tradycji ma charakter perswazyjny, a w istocie islamizm ma charakter „wywrotowy”, jego wyznawcy dążą do ustanowienia nowego ładu. Islam tradycyjny oznacza „poddanie się” człowieka woli Bożej, naucza jak żyć zgodnie z wolą Stwórcy i jest - jak przekonuje Daniel Pipes - „pewien swoich racji”, „odwołuje się do jednostki” oraz ,jest wiarą osobową”, podczas gdy islamizm jest „głęboko obronny”, „kolektywny”, a nade wszystko ,jest ideologią polityczną”. Por. D. Pipes, Islam i islamizm - wiara i ideologia, „National Interest”, wiosna 2000 r., http://pl.danielpipes.org/1235/islam-i-islamizm-wiara-i-ideologia

${ }^{6}$ Bośnia: „niebezpieczne tango” islamu z nacjonalizmem, 18 marca 2013, https://euroislam.pl/bosnianiebezpieczne-tango-islamu-z-nacjonalizmem/

7 Jak wyjaśnia Marko Babić istnieje zasadnicza różnica różnicę między terminami Boszniak (Bošnjak) a Bośniak (Bosanac). Ten drugi termin od stuleci oznacza mieszkańca obszaru geograficznego zwanego Bośnią bez względu na jego etniczną czy religijną przynależność, natomiast Boszniak (Bošnjak) stanowi termin polityczny, pojęcie identyfikacji narodu, którego członkami czują się muzułmanie w dzisiejszej Bośni i Hercegowinie. Jak pisze Babić: „Istniał on przynajmniej od czasów austro-węgierskiej okupacji, aby w trakcie konfliktu zbrojnego z lat 1992-1995 osiągnąć pełną akceptację polityczną muzułmańskiej części populacji BiH. Niektórzy przywódcy muzułmańscy (...) próbowali przedstawić ideę „boszniactwa” (bošnjaštva) jako wspólną ideę państwa Bośni i Hercegowiny, zamieszkałego przez narody różnych wyznań. Została ona odrzucona przez wyznawców prawosławia - Serbów, oraz katolików - Chorwatów, gdyż uważają oni termin „Boszniak” za całkowicie im obcy". Zob. M. Babić, Dramat tożsamości narodowej. Muzułmanie bośniaccy. https://www.researchgate. net/profile/Dr_Marko_Babic2/publication/235665983_Dramat_tozsamosci_narodowej_Muzulmanie_bosniaccy/ links/0912f5126cb71ce01d000000.pdf 
$\mathrm{BiH}$ jest krajem z większością muzułmańską ${ }^{8}$. Do wybuchu wojny domowej w latach dziewięćdziesiątych XX wieku tradycyjny islam bośniacki był umiarkowany i bardzo liberalny, niestety głębokie zmiany jego charakteru dokonały się - przynajmniej częściowo - pod wpływem arabskich mudżahedinów, którzy wsparli bośniackich muzułmanów w walkach z Serbami, a po zakończeniu wojny domowej pozostali w tym kraju.

Różnie można oceniać skalę zagrożenia ze strony islamistów w BiH. Wahhabizm oraz inne nurty radykalnego islamu są ruchami wstecznymi, które - mimo długiej historii nie stanowią siły rozwojowej, dlatego przywiązani do lokalnej tradycji umiarkowanego i postępowego islamu Boszniacy je odrzucą. Jednakże warto pamiętać, że kiedy w latach dziewięćdziesiątych XX wieku na Bałkanach Zachodnich pojawiły się nietolerancyjne idee, zbagatelizowano je, uznając ich propagatorów za niegroźnych wichrzycieli. Okazało się jednak, że ekstremiści z różnych stron politycznego sporu bardzo szybko przeszli od haseł i manifestacji do przemocy i zabijania tysięcy ludzi. Nie wolno zatem bagatelizować obecnej sytuacji, gdyż pogrążone w kryzysie społeczeństwo Bośni i Hercegowiny jest szczególnie narażone na oddziaływanie ruchów radykalnych.

Spośród wielu możliwych scenariuszy dla Bośni i Hercegowiny dwa warianty przyszłego rozwoju kraju są najczęściej obecne w dyskursie publicznym: albo tlący się konflikt będzie nadal trwał, co może doprowadzić do nowych aktów przemocy i dezintegracji kraju, albo skonsolidowanej Bośni i Hercegowinie uda się odbudować kapitał zaufania społecznego, a kraj pomyślnie zakończy integrację z Unią Europejską i NATO, co ostatecznie doprowadzi do trwałej stabilizacji sytuacji.

Niestety realizacja pożądanego scenariusza jest coraz trudniejsza. Pogłębiający się kryzys wewnątrz Unii Europejskiej oraz coraz mniej stabilna sytuacja na arenie międzynarodowej negatywnie oddziałują na procesy integracyjne. Co gorsza, dla wielu islamistów i nacjonalistów konflikt w Bośni i Hercegowinie nie zakończył się, a radykalne grupy islamskie liczą na jego „odmrożenie”. Wybuch gwałtownego zatargu w Bośni i Hercegowinie może bowiem być okazją dla islamskich ekstremistów do wystąpienia w roli prawdziwych obrońców bośniackich muzułmanów. Poza tym wiele sił i środowisk nacjonalistycznych W regionie Bałkanów próbuje instrumentalizować kwestię zagrożeń, przedstawiając siebie jako element europejskiego frontu w globalnej wojnie z islamskim terroryzmem.

Sytuację komplikuje fakt, iż Bośnia i Hercegowina nie pełni już wyłącznie funkcji bezpiecznego „schronienia” dla islamskich radykałów. Działania wojenne w Syrii, Iraku, międzynarodowy terroryzm, katastrofa ekonomiczna i społeczna w świecie muzułmańskim, prowadząca do horrendalnego kryzysu emigracyjnego, powodują, że dla wielu fundamentalistów BiH (a nawet cały region Bałkanów Zachodnich) to „brama” do

\footnotetext{
${ }^{8}$ Struktura narodowościowa i religijna w Bośni i Hercegowinie - podobnie jak w innych krajach regionu stanowi kolejne źródło konfliktu. Latem 2016 roku, kiedy opublikowano wyniku spisu powszechnego, według którego bośniaccy Muzułmanie stanowili większość populacji, przedstawiciele Serbów w zaprotestowali. Po gorącej dyskusji o metodologii spisu, opublikowano jego wyniki: 50,1\% populacji kraju to muzułmanie, podczas gdy 30,8\% mieszkańców zadeklarowało się jako Serbowie, natomiast 15,4\% jako Chorwaci. Głównym powodem krytyki wyników był fakt, że - jak twierdzili Serbowie - około 200 tysięcy muzułmanów uwzględnionych w spisie mieszka za granicą. Najnowsze wyniki spisu mogą prowadzić do naruszenia równowagi instytucjonalnej w BiH, ponieważ stanowiska w administracji rządowej czy instytucjach centralnych są podzielone pomiędzy trzy etniczne grupy, adekwatnie do udziału procentowego danej grupy w ogólnej populacji. Serbowie zdecydowanie odrzucają nowy podział.
} 
islamskiego podboju Europy. To właśnie dlatego, zdaniem wielu nacjonalistów - w Bośni, w regionie, a także w Europie - nadchodzą czasy ostatecznego starcia cywilizacji europejskiej z „wojującym islamem”. Ludność prawosławna - choć nie tylko ona liczy na przywództwo Rosji w ostatecznej zwycięskiej rozprawie z globalnym dżihadem. Dodatkowym elementem na geopolitycznej szachownicy jest rosnąca w siłę i zyskująca na arenie międzynarodowej, lecz także - niestety - islamizująca się Turcja, która mocno wspiera odtworzenie muzułmańskiej, a ściślej mówiąc „osmańskiej” tożsamości na Bałkanach.

\section{Wewnątrz wspólnoty muzułmańskiej w Bośni i Hercegowinie}

Sytuacja w Bośni i Hercegowinie uległa istotnej zmianie pod wpływem dyskusji, która rozpoczęła się w połowie pierwszej dekady XXI wieku. Na przełomie lutego i marca 2006 roku opublikowano ważne deklaracje dotyczące islamu, sygnowane przez muftiego Mustafę Cericia (oficjalnego przywódcę duchowego wspólnoty muzułmańskiej) oraz grupę piętnastu islamskich duchownych i misjonarzy z Bośni i Hercegowiny. Mufti zwrócił się do muzułmanów europejskich, zachęcając do instytucjonalizacji islamu w Europie. Ta deklaracja stanowi istotny wkład w szerszą debatę na temat „europejskiego islamu", która pojawiła się w dyskursie publicznym po atakach terrorystycznych w Nowym Jorku we wrześniu 2001 roku i która przybrała na sile po masakrze w Madrycie (w marcu 2004 r.) i wybuchu bomby w Londynie (w lipcu 2005 r.). Oddzielne apele zostały wystosowane do Unii Europejskiej, do muzułmanów mieszkających na kontynencie oraz do świata muzułmańskiego, a ich celem było zainicjowanie debaty na temat stworzenia „europejskiej kultury islamu” jako kultury odrębnej od narodowych wersji islamu? .

Jednak to stanowisko nie było reprezentatywne ani dla procesów zachodzących w Europie, ani dla zmian w Bośni i Hercegowinie. W rzeczywistości sytuacja była - i jest obecnie - całkowicie odmienna, ponieważ weszliśmy w fazę, w której narodowa, „boszniacka" interpretacja islamu - zgodna z sunnicką tradycją hanaficką ${ }^{10}$ - ulega gruntownym przekształceniom pod wpływem różnych formacji i szkół islamskich. Przywódcy ruchów radykalnych - zwłaszcza salafickiego i wahhabickiego - zarówno w BiH, jak i w ośrodkach muzułmańskich w całej Europie przedstawiają własne koncepcje, nazywając je ,uniwersalną perspektywą islamską". Radykałowie prezentują własne poglądy jako uniwersalistyczne i prawdziwie islamskie, krytykując jednocześnie bośniackich duchownych, którzy kładą większy nacisk na praktykowanie lokalnych tradycji religijnych, służących krzewieniu bośniackiej idei narodowej. Ekstremiści dążą natomiast do „oczyszczenia”

9 „Muzułmanie, którzy mieszkają w Europie, powinni przedstawić islam zachodniej publiczności jako uniwersalny pogląd na świat, a nie jako plemienną, etniczną lub narodową kulturę" - czytamy w deklaracji Cericia. Zob.: A Declaration Of European Muslims. http://www.rferl.org/a/1066751.html

${ }^{10}$ Hanafici (ar. حنفي) - zwolennicy jednej z czterech głównych sunnickich szkół prawa muzułmańskiego, wywodzącej się od teologa Abu Hanify (zm. 767). Szkoła hanaficka obecnie jest popularna w Turcji, na Bałkanach, Żyznym Półksiężycu oraz częściowo w Afganistanie i Pakistanie, i stanowi 35-40\% ortodoksyjnych muzułmanów. Uchodzi za najbardziej otwartą filozoficznie i religijnie spośród wszystkich szkół sunnickich. Większość polskich muzułmanów jest hanafitami. 
i ujednolicenia różnych narodowych wersji nauczania islamu. Jednak dla większości wierzących muzułmanów w Bośni i Hercegowinie ich narodowa tradycja islamska jest nadal korzystna, ponieważ „chroni” ich od jakiejkolwiek formy radykalnej interpretacji religii. Radykałowie powołują się tymczasem na islamskie prawo odwetu, mimo faktu, że bośniacka interpretacja tej zasady jest istotnie odmienna ${ }^{11}$.

Spór o „europejski islam” w kontekście Bośni wiąże się także z działalnością Mustafy Cericia na arenie międzynarodowej. Ścisła współpraca między religijnym przywódcą muzułmańskim a politykami zagranicznymi została skrytykowana przez wielu bliskich współpracowników sarajewskiego reis-ul-ulema. Rozpoczęto kampanię przeciwko Cericiowi, stawiając zarzuty, że jego kontakty z przedstawicielami obcych państw umożliwią zagranicznym agentom wywiadu spenetrowanie wspólnoty muzułmańskiej. Opublikowano też „Zieloną księgę”, zawierającą dokumenty z archiwum służby bezpieczeństwa na temat współpracy niektórych przywódców religijnych z przedstawicielami jugosłowiańskiego aparatu represji w okresie socjalizmu. Ofiary prześladowań z czasów SFRJ zażądały usunięcia współpracowników bezpieki z wpływowych stanowisk w islamskiej wspólnocie Bośni i Hercegowiny. Cerić odmówił, co doprowadziło do otwartej konfrontacji ze społeczeństwem, i w konsekwencji mufti stracił wpływy i poważanie w niektórych kręgach islamskich duchownych i polityków bośniackich.

\section{Religia i polityka}

Cerić próbował instrumentalizować międzynarodowe wsparcie dla umiarkowanego islamu w celu poprawy jego własnej pozycji w strukturze władzy i politycznych wpływów, aby finalnie przeforsować autorską koncepcję przyszłej konstytucji Bośni i Hercegowiny. Te kontrowersyjne strategie polityczne muzułmańskiego przywódcy doprowadziły do nieporozumień między europejskimi politykami a muftim Sarajewa, jeśli chodzi o wsparcie przez zagranicę umiarkowanego islamu w Bośni ${ }^{12}$.

Istnieje zatem szereg problemów wynikających z aktywności liderów religijnych w przestrzeni publicznej. Niektóre kraje zachodnie, intensyfikując kontakty dyplomatyczne z przywódcami muzułmańskimi ${ }^{13}$, de facto wspierają proces transformacji Bośni i Hercegowiny w kraj islamski. Istotnie, niektóre stolice europejskie zmieniły swoją politykę wobec Sarajewa, traktując BiH jako część tak zwanego „świata islamskiego” (lub jako kraj należący do grupy państw o większości muzułmańskiej), pomimo faktu, że

${ }^{11}$ Kolejnym przykładem zmagań między umiarkowaną, narodową wersją islamu w Bośni a jego radykalną, uniwersalistyczną odmianą jest dyskusja o łączeniu lokalnych tradycji islamskiej obrzędowości ze zwyczajami chrześcijańskimi w Bośni i Hercegowinie. Ta fundamentalna kwestia była źródłem gorącego sporu między tradycjonalistami a salafitami. Por. E. Hećimović, Radical movements - a challenge for moderate Balkan-Islam?, http://www.leviathan06.com/pdf_pool/publikationen/rel_exterm_vs_fried_beweg_05_radical_movements_moderate_balkan_islam_e_hecimovic_17.pdf

${ }^{12}$ Niektóre kraje europejskie, takie jak Wielka Brytania, Niemcy i Austria wsparły aktywność Cericia na poziomie międzynarodowym, ale wsparcie wynikało raczej z taktyki politycznej, polegającej na zachęcaniu przywódców religijnych - zwłaszcza muzułmańskich - do publicznego potępienia terroryzmu.

13 Wielu polityków odwiedziło główną siedzibę Cericia w Sarajewie, a dla niektórych dyplomatów zachodnich kontakty z przywódcą religijnym były co najmniej tak samo ważne jak spotkania z wysokimi rangą politykami $\mathrm{BiH}$. 
Biuro Wysokiego Przedstawiciela skrytykowało publiczne wezwania ze strony boszniackich duchownych do budowy państwa narodu muzułmańskiego. Z kolei intelektualiści w Sarajewie potępiają szkodliwe, ich zdaniem, wykorzystywanie religii do osiągania celów politycznych i narodowych, ingerencję religii w życie polityczne i zbyt bliskie związki muzułmańskich liderów z saudyjskimi lub wahhabickimi duchownymi. Ta krytyczna perspektywa stanowi ważny element procesu demokratyzacji społeczeństwa i politycznej transformacji Bośni i Hercegowiny ${ }^{14}$.

Najczęstszym argumentem ze strony przywódców religijnych broniących swego prawa do ingerencji w przestrzeń polityki jest ich dążenie do zachowania islamskiej legitymizacji władzy. Liderzy muzułmańscy w Bośni wielokrotnie zwracali się do zachodnich polityków, aby ci nie krępowali ich działań, bo inaczej przedstawiciele umiarkowanego islamu stracą kontrolę nad społeczeństwem na rzecz radykalnych islamistów. To oczywiście argument zasadny, ale z drugiej strony przywódcy religijni, cieszący się społecznym zaufaniem, nie powinni wykorzystywać swej pozycji i manipulować opinią publiczną (i społecznością międzynarodową) co do ich realnego wpływu na życie polityczne.

Zwodnicze wykorzystywanie międzynarodowego wsparcia dla umiarkowanych środowisk islamskich może przekształcić się w źródło potencjalnych konfliktów w Bośni i Hercegowinie. Dyskusja na temat politycznej i ustrojowej przyszłości Bośni i Hercegowiny stanowi bardzo delikatną kwestię, a brak wyraźnego odróżnienia między wspieraniem umiarkowanych poglądów islamskich a zakazem nadużywania religii do celów politycznych sprawia, że obecnie już napięta sytuacja może eskalować i prowadzić do dramatycznych skutków.

\section{Muzułmańskie tożsamości}

Jednym z elementów narracji o Bośni, którą posługują się islamscy liderzy, zwłaszcza duchowni, jest odwoływanie się do historycznych porównań między cierpieniami muzułmanów w Bośni podczas wojen w latach dziewięćdziesiątych XX wieku a prześladowaniami wspólnoty islamskiej w czasie rekonkwisty w średniowiecznej Hiszpanii. Porównywanie sytuacji muzułmanów w Bośni z ich położeniem w hiszpańskiej Andaluzji przez lata było wyraźną strategią perswazyjną islamistów, którzy przekonywali, że wyznawcy Proroka nie są akceptowani ${ }^{15}$ - przesłanie miało być czytelne i jednoznaczne: Zachód nie chce muzułmańskiego narodu w Europie, nawet 500 lat po zlikwidowaniu ostatniej muzułmańskiej enklawy w Granadzie. Takie stawianie sprawy było częścią szerszej próby stworzenia globalnej konfrontacji między islamem a Zachodem ${ }^{16}$.

Aby zrozumieć źródła narracji o ,zderzeniu cywilizacji”, musimy dostrzegać relacje między krwawą wojną w Bośni i Hercegowinie a tożsamością religijną jej mieszkańców. Przesłanie islamistów jest silne i wpływowe, ponieważ łączy cierpienie ofiar wojen-

14 E. Heć i mović, Radical movements...

15 Próby odnowienia historycznego konfliktu między wyznawcami Proroka a chrześcijańską Europą były między innymi pokłosiem religijnych interpretacji wydarzeń historycznych. Wpływowy bośniacki muzułmański duchowny, Mustafa Spahić, w artykule napisanym w 1993 roku pod tytułem Od Granady do Stupni widzi zbieżność między prześladowaniami muzułmanów w Hiszpanii przez inkwizycję a zbrodniami wojennymi popełnionymi wobec muzułmanów w Bośni i Hercegowinie. Por. E. He ć i m o v i ć, Radical movements...

${ }^{16}$ Por. R. Mahmutć e haj ić, The Denial of Bosnia, The Pennsylvania State University Press 2000. 
nych z ich samoidentyfikacją. Taka ideologiczna interpretacja konfliktu jest wzmacniana przez odwoływanie się do zrozumiałej dla muzułmanów kategorii domniemanej nienawiści „niewiernych” wobec islamu. Pamięć kolektywna została zredukowana do jej opisu w kategoriach nowej krucjaty przeciwko muzułmanom w Europie. Według tej koncepcji, ludobójstwo dokonane na muzułmanach w Bośni to boska kara za odstępstwo od islamu, a - w konsekwencji - powrót do prawdziwej wiary i utworzenie państwa islamskiego ma być sposobem na uniknięcie podobnej kary w przyszłości. Z islamskiego punktu widzenia, źródłem władzy nie może być wyłącznie siła militarna, ale powrót do prawdziwej wiary. Traumatyczne doświadczenie „oblężenia”, którego korzenie sięgają średniowiecza, miało ogromny wpływ na kształtowanie się współczesnej tożsamości muzułmańskiej w Bośni. Psychologiczny uraz, którego źródłem jest masowe cierpienie ludności muzułmańskiej, poczucie osamotnienia (porzucenia przez światową wspólnotę islamu) oraz wspomniane osaczenie przez chrześcijańskich wrogów utrwaliły się w zbiorowej świadomości muzułmanów w $\mathrm{BiH}$, a to oczywiście ułatwia rozprzestrzenianie się ideologii islamistycznej.

Część obserwatorów zdecydowanie odrzuca tezy o zagrożeniach ze strony islamizmu, wskazując, że stanowią one raczej element nachalnej serbskiej i chorwackiej propagandy, której celem jest podważenie prawomocności istnienia bośniackiego państwa. Zwykle twierdzi się, iż to mało prawdopodobne, aby islamizm stał się decydującą siłą w Bośni, gdyż większość jej mieszkańców pozostaje wierna tradycji umiarkowanej oraz - jak twierdzą niektórzy - zlaicyzowanej wersji islamu. Jednakże z licznych dowodów, dostarczonych zresztą głównie przez samych Boszniaków, wyłania się bardziej złożony i niepokojący obraz.

Bez wątpienia społeczność muzułmańska jest obecnie bardzo zróżnicowana, a nawet wewnętrznie skonfliktowana. Trzeba stale przypominać, że czasie wojny domowej do Bośni wjechało około dwóch tysięcy arabskich bojowników ${ }^{17}$, a wielu z nich - już po ustaniu walk - ożeniło się tu i osiedliło. Obecnie, wspierani milionami petrodolarów byli wojownicy Allaha stanowią rdzeń islamistycznych wpływów i napędzają radykalizację pozostałych muzułmanów, zwłaszcza w Sarajewie i wschodniej Bośni. Islamski obcy element napływowy w Bośni to dziś także wahhabici, którym - jak już przed laty zauważył teolog Resid Hafizović - udało się zakorzenić w bośniackich mediach, administracji religijnej, na uniwersytetach, w meczetach i szkołach koranicznych oraz instytucjach akademickich. Znamienne jest to, że wahhabici koncentrują się na oddziaływaniu na młodzież, a islamizacja kraju postępuje w zastraszającym tempie ${ }^{18}$.

W niestabilnym otoczeniu politycznym wzrost wpływów islamizmu jest szczególnie niepokojący, gdyż kontrastuje on z umiarkowaną postacią islamu, tradycyjnie praktykowaną w Bośni. Islamizm jako XX-wieczna ideologia polityczna opiera się na religii, a jego ostatecznym celem jest zastąpienie zachodniego prawa tradycyjnym prawem islamskim, szariatem w całym świecie. Gdyby tak się stało, to mielibyśmy do czynienia

${ }^{17}$ Między innymi filipiński założyciel radykalnych ugrupowań terrorystycznych Abu Sayyaf.

${ }^{18} \mathrm{~W}$ samym tylko Sarajewie w ciągu jednego dnia zmieniono nazwy 500 ulic i placów, wymazując pamięć o jakichkolwiek niemuzułmańskich bohaterach tego regionu. Innym niepokojącym obszarem islamizacji jest sfera edukacji. Na przykład minister edukacji w latach 2009-2012 Emir Suljagić (autor wspaniałej relacji dziennikarskiej z oblężonej Srebrenicy pt. Pocztówki z grobu) wycofał się z planów zlaicyzowania systemu szkolnictwa i podał się do dymisji, po otrzymaniu listu z pogróżkami i pociskiem $7.23 \mathrm{~mm}$. 
z naruszeniem fundamentów zachodniej demokracji, a to ze względu na odrzucenie praw stanowionych przez demokratycznie wybranych przedstawicieli ${ }^{19}$.

Aby zrozumieć, z czym mamy do czynienia, należy najpierw wskazać główne rodzaje islamizmu wpływające na obecną sytuację w Bośni. Islamistów dzieli się zwykle na dwie kategorie: islamistów uciekających się do przemocy, którzy prowadzą świętą wojnę, czyli dżihad, i czynią to w sposób otwarty oraz tych wyznawców islamu, którzy publicznie deklarują odrzucenie stosowania siły jako środka działań politycznych ${ }^{20}$. Jednak bliskie powiązania pomiędzy „gwałtownym” islamizmem i „pokojowym” islamem, które zwykle są negowane, w rzeczywistości naprawdę istnieją ${ }^{21}$. Dlatego też bardziej wartościowe poznawczo jest rozróżnienie trzech głównych grup muzułmańskich w Bośni. Są to: po pierwsze, środowiska związane z Bractwem Muzułmańskim, tj. grupą, której członkowie uczestniczą w instytucjach demokratycznych i często publicznie popierają zachodnie wartości; po drugie, muzułmanie zaangażowani w działalność terrorystyczną lub dżihad; oraz - po trzecie - wahhabici, czyli wyznawcy muzułmańskiej doktryny religijnej, głoszącej powrót do pierwotnej czystości islamu oraz surowości i prostoty obyczajów zwolenników saudyjskiego fundamentalizmu, którzy odrzucają zachodnie instytucje.

Niektórzy spośród wahhabitów mają związki z terroryzmem, natomiast inni terroryzm odrzucają. Pomiędzy wymienionymi grupami istnieją napięcia i spory, ale wszyscy zgadzają się co do ogólnego celu: zastąpienia prawa zachodniego islamskim szariatem. I wszystkie te trzy grupy wchodzą w stosunkowo bliskie relacje z bośniackimi elitami politycznymi i religijnymi ${ }^{22}$.

\section{Od Deklaracji Islamskiej do niepodległej Bośni i Hercegowiny}

Islamizm pojawił się w Bośni w 1941 roku, kiedy Alija Izetbegović i inni stworzyli organizację Mladi Muslimani, grupę wzorowaną na Bractwie Muzułmańskim. Słynny manifest polityczny Izetbegovicia z początku lat siedemdziesiątych XX wieku, Deklaracja Islamska, zawierał wiele islamskich pojęć, potwierdzając osobiste związki późniejszego lidera bośniackich muzułmanów z ideologią religijną.

19 Fundamentalną zasadą szariatu jest nierówność wobec prawa, co stanowi zaprzeczenie zachodniego ducha prawa. Transformacja w kierunku islamizmu ma być - zdaniem jej orędowników - zrealizowana w formie globalnego kalifatu lub islamskiego imperium, na czele którego stanie osoba będąca zarówno liderem politycznym, jak i religijnym.

${ }^{20} \mathrm{Z}$ wyjątkiem użycia siły przeciw Izraelowi lub armiom państw zachodnich walczących w krajach muzułmańskich.

21 Jest to szczególnie widoczne w krajach takich jak Egipt, Libia, Tunezja, Syria, gdzie Bractwo Muzułmańskie, najlepiej znane ugrupowanie reprezentujące islam ,pokojowy”, sięgnęło po władzę.

22 Islamiści są aktywni w całej Europie Zachodniej, a nawet w USA, jednak ich obecność w Bośni stanowi większe niebezpieczeństwo ze względu na powiązania - w przeszłości lub obecnie - ze sferą władzy reprezentowaną przez liderów politycznych - Bakira Izetbegovicia, Harisa Silajdžicia, a zwłaszcza ojca niepodległej Bośni, czyli Aliję Izetbegovicia. Zagrożenie ze strony islamistów w Bośni jest też większe ze względu na ich związki z Mustafą Cericiem, przywódca Islamskiej Wspólnoty BiH. Wymienione osoby - wraz ze swoimi współpracownikami i podwładnymi - prowadziły politykę wrogą nie tylko wobec Serbów i Chorwatów, ale również przeciwną koncepcjom umiarkowanych muzułmanów bośniackich. Do pewnego stopnia wspierali oni islamistyczny terroryzm, wahhabizm oraz propagowali separację między Boszniakami a niemuzułmańskimi mieszkańcami kraju, a nawet szukali bliższych więzi z krajami islamskimi, takimi jak Arabia Saudyjska i Iran. 
Stara historia niespodziewanie ożyła, gdy Izetbegović założył partię polityczną, a z byłych Młodych Muzułmanów uczynił wewnętrzny rdzeń tego ugrupowania, dzięki czemu udało mu się wymanewrować bardziej umiarkowanych politycznych rywali ${ }^{23}$, co doprowadziło go do objęcia stanowiska prezydenta Bośni w 1990 roku. Izetbegović pełnił tę funkcję w latach 1990-1996, a następnie, w okresie 1996-2000 był członkiem kolektywnego prezydium (stanowisko to rotacyjnie przechodzi między Serbem, Chorwatem i Boszniakiem $)^{24}$. Architekt niepodległej Bośni, pieszczotliwie nazywany przez Boszniaków „Dedo”, zmarł w 2003 roku, lecz jego spuścizna pozostaje nadal żywa. Długoletni współpracownik Izetbegovicia, Haris Silajdžić i syn, Bakir poszli w ślady swego nauczyciela: pełnili najwyższe funkcje w państwie i sympatyzowali z islamistami. Związki z Bractwem były ważne również dla innego prominentnego polityka bośniackiego starszego pokolenia, Mustafy Cericia, który przez lata był Wielkim Muftim Sarajewa, przywódcą Islamskiej Wspólnoty, a ponadto jest uważany za jedną z czołowych postaci politycznych w państwie. Dlatego też, choć mało się mówi i pisze na temat działalności Bractwa Muzułmańskiego w Bośni, to liderzy bośniaccy starszego pokolenia, którzy przez polityków zachodnich są postrzegani jako reprezentanci świeckich muzułmanów, w istocie wyraźnie sympatyzują z organizacją islamistyczną. Ich poglądy i skłonność do kierowania Bośni w stronę świata muzułmańskiego alienują Boszniaków i wzmagają wrogość ze strony bośniackich Serbów i Chorwatów.

Siłą napędową islamskiego aktywizmu w Bośni i Hercegowinie były przez lata wpływy zewnętrzne. Obce doktryny pochodzą z krajów muzułmańskich, takich jak Arabia Saudyjska, Iran i Malezja. Były one skutecznie realizowane za pośrednictwem rozmaitych form konkurencyjnych organizacji społeczno-politycznych i religijnych: organizacji islamskich ochotników wojskowych (inaczej mudżahedinów), misjonarzy islamskich i pracowników muzułmańskich agencji humanitarnych i pomocowych, bośniackich centrów islamskich i bośniackich władz, irańskiej misji w Bośni, a także misji dyplomatycznych i innych komórek pochodzących ze świata islamskiego ${ }^{25}$.

${ }^{23}$ Kiedy w Socjalistycznej Federalnej Republice Jugosławii nastał kryzys w latach osiemdziesiątych, podstawowym źródłem islamskiego przebudzenia w Bośni i Hercegowinie była aktywność „Młodych muzułmanów” pod przywództwem Aliji Izetbegovicia. Członkowie tej grupy zostali później założycielami partii SDA. „Młodzi muzułmanie” zaczęli od indoktrynacji islamskiej społeczności byłej Jugosławii przez utożsamienie pojęcia „narodu bośniackiego” z kwestią religijną, czyli przynależności do wspólnoty muzułmańskiej. Przedstawiciele tej wspólnoty - zwłaszcza jej duchowi przywódcy - mówią dziś o „tradycyjnym islamie bośniackim”, który - co warto podkreślić - jest rozumiany bardziej w kategoriach islamu praktykowanego w Turcji niż Arabii Saudyjskiej.

${ }^{24}$ Kolegialnym organem pełniącym funkcję głowy państwa jest Prezydium Bośni i Hercegowiny, w skład którego obecnie (od 17 listopada 2014 r.) wchodzą Bakir Izetbegović (Boszniak), Dragan Čović (Chorwat) oraz Mladen Ivanić (Serb).

${ }^{25}$ Warto przywołać w tym miejscu jedno źródło islamskiego aktywizmu w Bośni. Jesienią 1993 roku szejk Imad al-Misri opublikował broszurę programową o nazwie Attitudes we should change. Autor tej publikacji postulował radykalne zmiany w interpretacji islamu w Bośni i Hercegowinie. Szejk Imad był jednym z najważniejszych misjonarzy muzułmańskich w Bośni i Hercegowinie, gdzie pracował przez dziesięć lat w humanitarnych organizacjach pozarządowych. Był on także zaangażowany w działalność militarną. Został deportowany do Egiptu na początku października 2001 roku, gdzie został skazany na 10 lat więzienia z powodu wcześniejszych przestępstw. W swoim raporcie rocznym 2001, biuro antyterrorystyczne Departamentu Stanu USA stwierdziło, że al-Misri był członkiem egipskiej grupy terrorystycznej, znanej pod nazwami „El Dżihadu” lub „Grupa Islamska”. Organizacja ta figurowała nie tylko na specjalnej liście Departamentu Stanu obejmującej ugrupowania terrorystyczne, ale również we wszelkich innych zestawieniach sprawców i sponsorów terroryzmu, sporządzonych przez zachodnie rządy i ONZ. 
Obecnie wpływ zagranicznych doktryn dotyczących muzułmańskich społeczności w Bośni nieco się zmniejszył. Pojawiła się za to nowa generacja islamskich duchownych w Bośni, wykształconych już po wojnie na islamskich uniwersytetach Arabii Saudyjskiej, Jordanii, Syrii i innych krajów. Nowe pokolenie liderów duchowych cechuje znacznie lepsze zrozumienie procesów religijnych i politycznych w krajach islamskich. Istotny jest fakt, że wpływowymi duchownymi nie są już cudzoziemcy, lecz obywatele Bośni i Hercegowiny, zakorzenieni w lokalnych społecznościach. Dziś już coraz trudniej odróżnić „importowane” i ,lokalne” wersje islamu w Bośni i Hercegowinie. Trudno obecnie wytyczyć jasną linię podziału pomiędzy różnymi źródłami wpływu i determinantami islamskiego odrodzenia w Bośni i Hercegowinie, zwłaszcza po wielu latach gorącej debaty w ramach różnych grup i organizacji muzułmańskich w Bośni i Hercegowinie, dotyczącej właściwego nauczania i praktykowania islamu.

Rozwój islamu na Bałkanach może być zatem postrzegany jako konsekwencja rozmaitych czynników od końca okresu socjalistycznego i rozpadu Jugosławii, takich jak cierpienia bośniackich muzułmanów podczas wojny, zaangażowanie zagranicznych bojowników pochodzących z krajów islamskich, których spora liczba pozostała w Bośni i Hercegowinie po zakończeniu wojny, oraz islamska praca misyjna zmierzająca do zbudowania prawdziwego muzułmańskiego narodu. Wielu spośród muzułmańskich duchownych można by określić mianem islamistów, jeśli definiować pojęcie „islamizmu” jako wykorzystywanie islamu w charakterze ideologicznego narzędzia służącego osiąganiu celów politycznych. Prowadzone dziś dyskusje koncentrują się na tym, które spośród ugrupowań muzułmańskich są bardziej islamistyczne, bardziej skuteczne, efektywne czy pożyteczne dla muzułmańskiej wspólnoty w BiH, a które - wręcz przeciwnie - stanowią niezgodną z doktryną religijną emanację wojowniczego islamu i które de facto szkodzą bośniackim muzułmanom.

\section{Dżihadyści: Bośnia i Hercegowina jako schronienie terrorystów czy brama do podboju Europy?}

Ogromnym impulsem dla rozwoju islamizmu w Bośni było przybycie islamskich bojowników, którzy zdecydowali się walczyć po stronie muzułmanów w czasie wojny w latach 1992-1995. Wartość bojowa mudżahedinów dość szybko została zakwestionowana, ale towarzyszące im wsparcie finansowe i wojskowe z Arabii Saudyjskiej oraz Iranu okazało się niezbędne dla bośniackiego wysiłku wojennego. I chociaż obydwa wymienione kraje są politycznymi i religijnymi rywalami, to skutecznie pomogły mudżahedinom w Bośni. Arabia Saudyjska koncentrowała się na finansowaniu i dostawach logistycznych, natomiast Iran przede wszystkim „eksportował” bojowników i niezbędną pomoc wojskową ${ }^{26}$.

Na krwawej wojnie domowej skorzystała także Al-Kaida, zarówno pod względem organizacyjnym, jak i w procesie rekrutacji nowych członków ${ }^{27}$, a konflikt zbrojny na

${ }^{26} \mathrm{Ch} . \mathrm{D}$ e 1 is o, The Coming Balkan Caliphate: The Threat of Radical Islam to Europe and the West, Westport, CT: Praeger Security International, 2007, s. 8.

${ }^{27}$ E. Kohlman n, Al-Qaida's Jihad in Europe: The Afghan-Bosnian Network, Oxford, UK: Berg, 2004, s. xii-xiii. 
Bałkanach przyczynił się do radykalizacji wielu europejskich muzułmanów. Przyszłych globalnych terrorystów islamskich poruszyły obrazy telewizyjne, fotografie i przekazy prasowe ilustrujące straszliwy los i cierpienia muzułmanów. Pewna część muzułmanów z krajów europejskich udała się do Bośni, aby wesprzeć swoich współwyznawców, a nawet włączyć się bezpośrednio w walkę. Tym sposobem mieszkańcy regionu weszli w kontakt z zagranicznymi dżihadystami ${ }^{28}$.

Władze niepodległej Bośni, wspierane przez wspólnotę międzynarodową, próbowały zwalczać terroryzm islamski. Do najbardziej znanych akcji w tej dziedzinie należy zaliczyć dokonany w 1996 roku nalot IFOR na irański terrorystyczny obóz szkoleniowy w Pogorelicy, a także liczne kroki podjęte po atakach terrorystycznych z 11 września 2001 w Stanach Zjednoczonych. W tym czasie SFOR udaremnił zamachy terrorystyczne wymierzone w NATO i inne cele zachodnie. Podjęto także działania przeciwko Saudyjskiej Wysokiej Komisji i innym islamskim organizacjom charytatywnym na terenie Bośni, które podejrzewano o finansowanie organizacji terrorystycznych.

W 2004 roku ekspert ds. terroryzmu Evan Kohlmann - w publikacji na temat o afgańsko-bośniackich relacji terrorystycznych, stwierdził, że Al-Kaida poniosła klęskę i nie udało się jej zakorzenić w BiH. Autor zauważył postępy w udaremnianiu rozmaitych operacji terrorystycznych i wyraził opinię, że Al-Kaida przegrała, ponieważ umiarkowani Bośniacy odrzucili jej ekstremistyczną ideologię ${ }^{29}$. Jednak te wnioski są chyba przedwczesne i nazbyt optymistyczne. Można wymienić liczne działania na terenie Bośni od połowy lat 90. XX wieku, które stanowią dowód aktywności międzynarodowej sieci terrorystycznej ${ }^{30}$.

${ }^{28}$ Wielu islamskich bojowników wykorzystało nabyte podczas wojny w Bośni umiejętności do późniejszych akcji terrorystycznych przeciwko celom europejskim i amerykańskim. Od zakończenia wojny w 1995 roku, bośniaccy weterani z różnych krajów zmieniali fronty walk oraz angażowali się w działania terrorystyczne w wielu krajach na całym świecie - we Francji, Indonezji, Iraku, Malezji, Maroku, Rosji, Arabii Saudyjskiej, Hiszpanii, Tajlandii, Wielkiej Brytanii, USA oraz Jemenie. Por. J. R. S c h in d1 e r, Unholy Terror: Bosnia, Al-Qa'ida, and the Rise of Global Jihad, St. Paul, MN: Zenith Press, 2007, s. 295-309.

29 E. Kohlmann, Al-Qaida's Jihad in Europe, s. 224-225.

30 Jeśli dokonać analizy serii wydarzeń i działań od 1996, to okaże się, że Bośnia i Hercegowina funkcjonowała jako aktywny element sieci Al-Kaida. Lista działań ze strony międzynarodowego terroryzmu islamskiego na terenie BiH jest długa: * od 1996 roku przywódcy mudżahedinów, tacy jak Abu el-Ma'ali i Abu al-Makki Sulaimann, którzy żyli jako „cywile” w miejscowości Bocinja Donja, w istocie nadzorowali spiski terrorystyczne we Francji, Włoszech i Jordanii; * w 2008 roku Biuro Wysokiego Przedstawiciela (OHR) w Sarajewie odkryło dowody, że podpis jednego z bośniackich polityków Hasana Cengicia widnieje na przelewie przeznaczonym na finansowanie ataków z 11 września w Nowym Jorku; * Karim Said Atrnani, fałszerz dokumentów w grupie przygotowującej zamach bombowy w 2000 roku, był częstym gościem w Bośni; po raz pierwszy uzyskał on bośniacki paszport w 1995 roku, a następnie pozwolono pozostać mu bez ważnego paszportu, po tym jak został deportowany przez Kanadę w 1998 roku; * pod koniec października 2001 Algierczycy z bośniackim obywatelstwem zostali aresztowani przez władze bośniackie pod zarzutem planowania aktu terrorystycznego polegającego na porwaniu niewielkiego samolotu z lotniska Visoko, a następnie rozbiciu go w samobójczym ataku na bazy SFOR w Tuzli i Bratunacu; * w 2005 roku planowano zamach bombowy w czasie pogrzebu Jana Pawła II, a jego główni architekci - jak donosiły media - najprawdopodobniej pochodzili z Gornja Maoca - spisek polegał m.in. na przemycie wyrzutni rakiet, materiałów wybuchowych i zapalników do Włoch; * również w 2005 roku, w wyniku nalotu policyjnego bośniackich organów ścigania na mieszkania powiązane z grupą starającą się wysadzić w powietrze ambasadę brytyjską w Sarajewie, dokonano zajęcia materiałów wybuchowych, karabinów, innej broni oraz wideo propagującego akt zemsty ze strony dżihadystów za zabitych w Afganistanie i Iraku; jeden z aresztowanych, szwedzki obywatel pochodzenia bośniackiego, prowadził stronę internetową w imieniu Abu Musab Zarkawiego, przywódcy Al-Kaidy w Iraku; * w 2006 roku aresztowano grupę Bosniaków i Macedończyków powiązanych 
Także Irańczycy nie opuścili Bośni po akcji antyterrorystycznej w 1996 roku ${ }^{31}$, a po dokonanym w lipcu 2012 roku ataku terrorystycznym na lotnisku w Burgas w Bułgarii, międzynarodowa uwaga koncentruje się na możliwych zagrożeniach ze strony Hezbollahu na całych Bałkanach. Izraelscy eksperci twierdzą, że Bośnia i Hercegowina stanowi obecnie największe zagrożenie w regionie, ponieważ elementy proirańskie są obecne w bośniackim rządzie, a Iran jest aktywny na tym terenie za pośrednictwem ambasad w Sarajewie i organizacji charytatywnych ${ }^{32}$.

Terroryzm islamski funkcjonuje w Bośni w ramach struktur Al-Kaidy, pod wpływem Iranu, ale także otrzymuje wsparcie z rodzimych źródeł. Różne są oceny stanu zagrożenia. Wielu zachodnich analityków odrzuca tezę o zagrożeniu terrorystycznym w Bośni, nie dostrzegając wagi problemu ${ }^{33}$. Inaczej oceniają sytuację niektórzy przedstawiciele bośniackich organów ścigania, którzy twierdzą, że jedynym powodem ograniczonej liczby ataków terrorystycznych jest po prostu szczęście ${ }^{34}$, gdyż liczba osób zaangażowanych w terroryzm na terenie Bośni jest znaczna ${ }^{35}$.

Z przedstawionych opinii i faktów można wyciągnąć co najmniej dwa wnioski. Po pierwsze, poziom aktywności terrorystycznej w Bośni jest porównywalny do poziomu w innych krajach Europy, chociaż temu optymizmowi powinna towarzyszyć daleko idąca ostrożność. Po drugie, tylko dlatego, że zagrożenie terrorystyczne nie jest niczym niezwykłym w naszych czasach, nie znaczy, że jest ono nieważne. Porównania z Europą Zachodnią są zwodnicze, gdyż terroryzm jest znacznie bardziej niebezpieczny dla kruchej stabilizacji w Bośni niż skonsolidowanych państw demokracji zachodnich.

Niemniej istnieją także powody do optymizmu. Ewolucję islamskich radykałów na terenie BiH znakomicie ilustruje postać szejka Salmana al-Awdaha, jednego z przywódców islamskiej opozycji w Arabii Saudyjskiej ${ }^{36}$, który - początkowo - uznał konflikt w Bośni i Hercegowinie za „wojnę między islamem a chrześcijaństwem”, stał się gorącym orędownikiem islamskiego dżihadu na terenie Bośni i Hercegowiny, będąc równocześnie bliskim

z Al-Kaidą w północnych Włoszech po przemycie broni ze Stambułu. Źródła: Evan F. Kohlmann, Al-Qaida’s Jihad in Europe: The Aghan-Bosnian Network, New York, Berg, 2004, s. 176-199 oraz 201-209; Bosnia-Herzegovina Federation public TV. May 5. 2008. The Washington Post. March 11. 2000; Channel 4 News, January 17.2002: ISN. November 17, 2008; The Washington Post. December 1. 2005; Christopher Deliso. The Coming Balkan Caliphate: The Threat of Radical Islam to Europe and the West, Westport. CT. Praeger, 2007, s. 26.

31 Przedstawiciele irańskiego Ministerstwa Wywiadu i Bezpieczeństwa Narodowego (VEVAK) oraz wysłannicy Korpusu Strażników Rewolucji Islamskiej (IRGC) nadal działają na terenie BiH. Zwłaszcza ta druga instytucja ma rozległą sieć oddziaływania. Por. S. Mija to vi c, Tajna Diplomatska Ofanziva Iranaca u BiH, „Slobodna Bosna”, October 25, 2012.

${ }^{32}$ Ch. Delis o, Israeli Security Concerns and the Balkans, Balkananalysis.com, March 31, 2013, s. 14.

${ }_{33} \mathrm{Na}$ przykład przedstawiony w 2013 roku raport, przygotowany na zlecenie Kongresu USA w sprawie Bośni, zawiera wyłącznie krótkie wzmianki na temat terroryzmu, a raporty Departamentu Stanu i instytucji europejskich sugerują, że stopień zagrożenia terroryzmem w Bośni nie jest większy niż gdzie indziej w Europe. Country Reports on Terrorism, Washington, DC: US Department of State, May 20,2013; and EU Terrorism Situation and Trend Report, Te-Sat, European Police Agency, 2013.

${ }^{34}$ Por. V. A zin o v i c, K. B a s s u e n e r, B. We be r, Assessing the Potential for Renewed Ethnic Violence in Bosnia and Herzegovina: A Security Risk Analysis, Berlin, Germany: Atlantic Initiative and Democratization Policy Council, October 2011, s. 69.

35 Almir Dzuvo, dyrektor Agencji Wywiadu i Bezpieczeństwa BiH (OSA), oszacował, że w lipcu 2010 roku w Bośni - państwie liczącym niespełna cztery miliony mieszkańców - pozostawało około trzech tysięcy (!) aktywnych i potencjalnych terrorystów. Por. A zi novi c, B as su en er, We be r, A Security Risk Analysis, s. 65-66.

${ }^{36}$ Salman al-Awdah został aresztowany w 1994 roku przez władze saudyjskie i spędził w więzieniu pięć lat. 
współpracownikiem Osamy bin Ladena. Jednak na początku XXI wieku, podczas swojej wizyty w Sarajewie ${ }^{37}$, szejk al-Awdah ostrzegł wspólnotę muzułmańską w Bośni i Hercegowinie o niebezpieczeństwie ze strony radykalnych, „takfirskich" ${ }^{38}$ ugrupowań ${ }^{39}$. W swym publicznym wystąpieniu udzielił wprawdzie wsparcia pracy misyjnej, ale odrzucił jednocześnie walkę zbrojną jako środek do osiągania celów politycznych. Zmiana ta jest ważna dla zrozumienia procesu przejścia od „saudyjskiego” radykalizmu do „bośniackiego umiarkowania”: ktoś, kto niegdyś opisał konflikty w Bośni i Hercegowinie jako „wojnę religijną”, obecnie wzywa muzułmanów, aby mocniej integrowali się w europejskim społeczeństwie.

\section{Wahhabici: obcy wśród Boszniaków}

W 1996 roku jeden z liderów mudżahedinów stwierdził, że zagraniczni bojownicy nie będą stanowić problemu dla Bośni, ponieważ „ruszą dalej”, ale przybysze z Bliskiego Wschodu „zasiali ziarno”, którego plonem miała być coraz większa liczba bośniackich muzułmanów praktykujących tradycyjny islam ${ }^{40}$. Najbardziej oczywistym objawem tego trendu jest aktywność wahhabitów, czyli wyznawców islamu fundamentalistycznego, praktykowanego w Arabii Saudyjskiej. Szacunki dotyczące wielkości tej grupy (i liczby członków podobnych sekt) są zróżnicowane, lecz bez wątpienia jest to znaczna społeczność na terenie $\mathrm{BiH}^{41}$.

Wahhabici rekrutują swych wyznawców z ubogich warstw społeczeństwa bośniackiego. Grupą docelową ich indoktrynacji religijnej jest głównie młodzież, która ma bardzo ograniczone możliwości ekonomiczne, znajduje się w trudnej sytuacji i najczęściej pochodzi z obszarów wiejskich. Wahhabici skutecznie wykorzystują ubóstwo, brak edukacji i słabość systemu świadczeń socjalnych, oferując młodym ludziom i uchodźcom

${ }^{37}$ Jedna z wizyt Al-Awdaha w Bośni i Hercegowinie - który obecnie prezentuje znacznie bardziej umiarkowane poglądy - miała miejsce w maju 2007 roku. Odwiedził on Sarajewo jako delegat European Council on Fatwa and Research (ECFR) i był gościem Mustafa Cericia, reprezentującego Islamską Wspólnotę w Bośni i Hercegowinie.

${ }^{38}$ W celu zrozumienia zjawiska „fundamentalizmu” w Bośni i Hercegowinie ważne jest, aby uporać się z terminem takfir. Termin ten odnosi się do odstępstwa od „prawdziwego” islamu. Określenie to jest centralnym punktem debaty między różnymi grupami islamskimi, m.in. Bośni i Hercegowinie czy Sandżaku, a także w Europie Zachodniej. Wyraz takfirzy jest zwyczajową etykietą, której intelektualiści islamscy używają do krytyki islamskich ekstremistów.

39 Szejk al-Awdah jest znany z przesłania do Osamy bin Ladena, które wygłosił na żywo w telewizji NBC w dniu 14 września 2007 roku, opowiadając się przeciwko zabijaniu niewinnych ludzi, ale także przeciwko wyniszczaniu ludności Iraku i Afganistanu. W tym publicznym wystąpieniu potępił bin Ladena, stwierdzając, że „różnica między tym, kto zabija ludzi, a tym, kto ludzi wprowadza na ścieżkę islamu jest oczywista”.

${ }^{40}$ V. S k o c a j ić, A. A li ć, Understanding Bosnia, Part Four, ISN Security Watch, March 12, 2009.

${ }^{41}$ Dużym zaskoczeniem dla postronnych obserwatorów było chociażby zgromadzenie się ponad 3 tysięcy osób (z czego połowę stanowili Boszniacy) na pogrzebie przywódcy wahhabitów w 2007 roku. Por. A. Alic, Wahhabism: from Vienna to Bosnia, ISN, April 6, 2007. Pewną niespodzianką była też wysoka liczba uczestników konferencji w 2013 roku w Tuzli, która przyciągnęła 500 uczestników, głównie młodych mężczyzn. Zob. R. Coals on, M. Nikoli c, Radical Islamists Seek to Exploit Frustration in Bosnia, RFE/RL, March 1, 2013. Zważywszy, że szacunkowo około 4 tysięcy osób gromadzi się w każdy piątek, aby usłyszeć radykalne kazania głoszone we wspieranym przez Saudyjczyków meczecie króla Fahda w Sarajewie, liczba wahhabitów w Bośni jest wysoka. Zob. W. M a y r, Islamists Gain Ground in Sarajevo, „Islamist Watch”, February 25, 2009. Z najbardziej wiarygodnych szacunków bośniackiej policji federalnej wynika, że w 2009 roku praktykujących wahhabitów było na terenie $\mathrm{BiH}$ około 5 tysięcy. 
możliwość zatrudnienia oraz - co bardzo istotne - poczucie przynależności do wspólnoty. Zdarzały się przypadki, że nowym członkom płacono kilkaset euro miesięcznie za ich lojalność. Istnieją również dowody, że członkowie sekty wahhabitów są opłacani za przekonanie swych żon do noszenia hiḋ̇abu w miejscach publicznych.

Decydującą rolę w opisywanych procesach odgrywa rzecz jasna królestwo Saudów. Saudyjczycy sfinansowali ambitny program rekonstrukcji meczetów zniszczonych w wyniku wojny oraz budowy nowych świątyń, z których najbardziej znaną jest meczet króla Fahda ${ }^{42}$; budowa tego obecnie najbardziej wpływowego ośrodka religijnego w Bośni kosztowała 30 milionów dolarów. Równocześnie Arabia Saudyjska wsparła utworzenie równoległej struktury edukacyjnej o charakterze religijnym, funkcjonującej obok istniejących instytucji oświatowych prowadzonych przez Wspólnotę Islamską ${ }^{43}$. Saudyjczycy finansują też rozmaite grupy wahhabickie, które wysyłają młodych Bośniaków na studia do Rijadu, a także lokują własnych agentów w Bośni, zazwyczaj biorących sobie miejscowe kobiety za żony i wtapiających się w społeczność lokalną ${ }^{44}$.

Gdy ruch wahhabicki urósł w siłę, jego wyznawcy gwałtownie starli się z tradycyjnymi Boszniakami, starając się narzucić własne normy społeczeństwu BiH. Młodzi i charyzmatyczni kaznodzieje wahhabiccy podróżują po Europie Zachodniej i Bałkanach, wygłaszając płomienne kazania i wykłady, prowadzą popularne witryny internetowe, gdzie łatwo znaleźć wiele odniesień do dżihadu, islamską propagandę, a nawet podżeganie do terroru, a zwłaszcza działań wymierzonych w USA ${ }^{45}$.

Przemoc ze strony wahhabitów oraz ich nachalny prozelityzm są widoczne, jednak ich społeczność jest najbardziej znana - w Europie i świecie - z tworzenia separatystycznych enklaw, które funkcjonują poza kontrolą ze strony władz. Mieszkańcy tych zamkniętych obszarów odrzucają autorytet bośniackiego państwa i prawa, a zamiast nich wprowadzają własną interpretację szariatu. Jedna z pierwszych enklaw wahhabickich został utworzona w miejscowości Bocinja Donja, dawniej serbskiej wsi, gdzie rząd sarajewski postanowił osiedlić zagranicznych weteranów wojennych.

Mudżahedini pożenili się z miejscowymi muzułmankami i tą drogą uzyskali bośniackie obywatelstwo. Wieś stała się ich bezpiecznym schronieniem, w którym mogli utrzy-

42 S. Pogg i oli, Radical Islam Uses Balkan Poor To Wield Influence, NPR, October 25, 2010.

${ }^{43}$ Zob. S. Olu ić, Radical Islam on Europe's Frontier-Bosnia \& Herzegovina, ,National Security and the Future", Vol. 1-2, No. 9, 2008, s. 42; oraz Ioannis Mich ale to s, An Outlook of Radical Islamism in Bosnia, „Pakistan Christian Post”, July 2, 2012.

44 Saudis Tied to Domineering Wahabi Presence in Bosnia, WorldTribune.com, March 27, 2007.

45 Jeden z misjonarzy tego nurtu znany jest na przykład ze swojej prodżihadystowskiej, skrajnie antyamerykańskiej piosenki, która zdobyła ogromną popularność i którą wykonuje na weselach i innych uroczystościach. Słowa tego utwory są następujące: „Amerykańscy i inni przeciwnicy powinni wiedzieć, że teraz muzułmanie są jednością jak talibowie | Posłuchajcie bracia | Wierzący tego świata |Z dynamitem na piersiach | Prowadź ścieżką do dzennet (nieba)". Niektórzy Boszniacy zawsze mieli antyamerykańskie nastawienie, ale zdecydowana większość była głęboko wdzięczna Stanom Zjednoczonym za interwencję, która przyczyniła się do zakończenia wojny, a następnie utrzymania kruchego pokoju. Niestety nie istnieją wyniki wcześniejszych badań społecznych, które pozwoliłyby oszacować dynamikę zmiany poglądów i postaw wobec USA. Jest jednak mało prawdopodobne, aby młodzi ludzie urodzeni w trakcie lub po zakończeniu wojny przejawiali poczucie wdzięczności wobec Waszyngtonu. Trudno też oczekiwać, żeby nawet starsze pokolenia miały poczucie zobowiązania wobec USA za wdrożenie systemu politycznego w ramach porozumienia z Dayton, systemu, który po prostu zawiódł. Zob. N. P e j i ć, Wahhabist Militancy in Bosnia Profits from Local and International Inaction, „The Jamestown Foundation, Terrorism Monitor", Vol. 9, Issue 42, November 17, 2011. 
mywać kontakty z organizacjami terrorystycznymi, najczęściej udając prostych rolników. Już w latach dziewięćdziesiątych XX wieku wrogość mieszkańców opisywanej wioski wobec świata zewnętrznego - w tym oddziałów SFOR - była jawnie manifestowana, co podważało wcześniejsze deklaracje mieszkańców miejscowości o ich pokojowym nastawieniu. Ostatecznie enklawa została zamknięta, a wieś wróciła do swoich pierwotnych właścicieli. Obecnie najbardziej znaną enklawą wahhabitów jest Gornja Maoča, odległa wieś, gdzie rodzimi Boszniacy mieszkają obok urodzonych za granicą byłych mudżahedinów.

Bośniaccy Serbowie nie mają złudzeń co do islamistycznych no-go zones, które - ich zdaniem - stwarzają poważne zagrożenie dla bezpieczeństwa państwa. Niejednoznaczna jest natomiast postawa Boszniaków wobec enklaw zamieszkanych przez przybyszów z Bliskiego Wschodu oraz polityka władz BiH w tej kwestii. Próbowano izolować wahhabitów, w nadziei, że za jakiś czas problemy znikną. Podjęto nawet pewne starania na rzecz ograniczenia islamistycznej agitacji do odległych miejsc, lecz takie ukrywanie problemu, jego marginalizowanie przez wypychanie na obrzeża sfery publicznej nie jest tożsame ze strategią rozwiązania niebezpiecznej kwestii za pomocą instrumentów prawnych ${ }^{46}$.

Nie oznacza to, że nie podjęto żadnych kroków prawnych. Władze dokonały licznych aresztowań, zwłaszcza w trakcie akcji policyjnej przeprowadzonej w 2010 roku w enklawie Gornja Maoča. Zatrzymano ponadto dwóch liderów wspólnoty wahhabickiej podejrzanych o współudział w ataku na ambasadę USA w Sarajewie w 2011 roku ${ }^{47}$. Niestety długo nie udawało się sporządzić aktu oskarżenia, nie mówiąc już o skazaniu podejrzanych. W rezultacie aura tajemnicy, która od pewnego czasu utrzymuje się nad obszarem Gornja Maoča i innymi enklawami wahabitów, sprawia, że trudno określić stopień zagrożenia, jakie stanowią one dla bezpieczeństwa wewnętrznego Bośni, zwłaszcza biorąc pod uwagę ich potencjalne powiązania $\mathrm{z}$ międzynarodowym terroryzmem.

Bez wątpienia wielu wahhabitów to ludzie nastawieni pokojowo, których nie powinno się uznawać za terrorystów, gdyż taka stygmatyzacja może wywołać ich radykalizację i wepchnąć w orbitę wpływów grup uciekających się do przemocy politycznej ${ }^{48}$. To dlatego Islamska Wspólnota, oficjalna muzułmańska organizacja religijna w Bośni, odmówiła publicznego potępienia wahhabitów, a nawet wystąpiła przeciwko ich krytykom. Niemniej jednak opinia publiczna w Bośni pozostaje nieufna wobec obcych wpływów islamistycznych ${ }^{49}$.

Wahhabici jak dotąd nie uzyskali kontroli nad jakąkolwiek istotną rządową agendą lub oficjalnym urzędem religijnym. Nie udało im się również utworzyć wyizolowanych stref poza kontrolą władz w obszarach miejskich, z czym mamy do czynienia w Europie

${ }^{46} \mathrm{Sch}$ wartz, Bosnia Re-arrests Top Wahhabi Plotter.

${ }^{47}$ Warto wspomnieć, że ujętym wykonawcą zamachu był Boszniak z sąsiedniego Sandžaka (Republika Serbii), którego mieszkańcy utrzymują ścisłe kontakty z muzułmanami z BiH, a Wspólnota Islamska w Serbii podlega Wspólnocie Islamskiej w BiH.

48 J. Carlos A n t un e z Mor e n o, Foreign Influences in Islam in Bosnia and Herzegovina since 1995, The Islam in South East Europe Forum (ISEEF), Sarajevo, Bosnia, 2010.

${ }^{49}$ Kiedy w badaniach społecznych zmierzono postawy Boszniaków wobec wahabitów, to okazało się 71 proc. respondentów odrzuca ten saudyjski nurt, uznając, że ta forma islamu jest całkowicie odmienna od tradycyjnego islamu bośniackiego, a zatem jest obca i w Bośni niepożądana. Zob. Vast Majority of Bosnian Federation TV Viewers See Wahhabism as a Threat, BBC, December 10, 2006. 
Zachodniej. Najprawdopodobniej jest to wynikiem zdecydowanego sprzeciwu lokalnych Boszniaków. Na przykład próby przejmowania kontroli nad niektórymi meczetami zakończyły się aktami przemocy, a znaczna część bośniackich muzułmanów odnosi się do wahhabitów z nieskrywaną pogardą ${ }^{50}$.

Równocześnie wiele źródeł sugeruje, że nastąpiła większa radykalizacja postaw mieszkańców BiH w porównaniu ze schyłkiem lat dziewięćdziesiątych XX wieku. A więc skoro mamy do czynienia z niebezpieczną tendencją, wielce nierozważne byłoby ignorowanie wpływów wahhabickich w społeczeństwie bośniackim. Egzotycznych radykałów islamskich ekspert z Sarajewa Resid Hafizović nazywa wprost „,potencjalnie śmiertelnym wirusem" zagrażającym bośniackim muzułmanom ${ }^{51}$. Tym bardziej, że gdy czasy są trudne, a przyszłość niepewna, ruchy ekstremalne - także religijne - mogą rozwijać się bardzo dynamicznie ${ }^{52}$.

\section{Halafici kontra wahhabici - bliższe spojrzenie}

Debata pomiędzy tradycjonalistami i wahhabitami ma ogromne znaczenie dla przyszłości Bośni i Hercegowiny. Przedstawiciele głównego nurtu muzułmańskiej społeczności w Bośni i Hercegowinie wielokrotnie krytykowali błędną interpretację islamu ze strony radykałów oraz wzywali do ochrony wielowiekowej tradycji islamskiej w tym bałkańskim

50 Jeden z Boszniaków powiedzial: ,[Wahhabici] powinni ogolić brody i używać dezodorantu, zamiast przychodzić tutaj jak psy. Dla mnie są oni wilkami, które będą atakować nasze dzieci. Mam córki i nie odważyłbym się wysłać ich do szkoły religijnej”.

Cyt. za S. S chw artz, Bosnia Cracks Down on Wahhabism, ,The Weekly Standard”, February 18, 2010.

${ }_{51}$ B. Kanzle it er, Wahhabi Rules: Extremism Comes to Bosnia, ,,World Politics Review”, May 2, 2007.

52 Ostatnio sytuacja w Bośni i Hercegowinie uległa niestety pogorszeniu. Jak czytamy w raporcie Conflict Barometer z 2015 roku, zagrożenie radykalnym islamem na Bałkanach jest nadal duże, czego dowodem może być skazanie kilkunastu islamskich bojowników walczących za granicą na terenie wielu krajów, ale - co znamienne - do gwałtownych starć z użyciem przemocy między rządem a islamistycznymi bojówkami doszło jedynie w Bośni i Hercegowinie. W 2014 r. nasilił się spór między wahhabickimi bojownikami a rządem. Przedmiotem sporu, który rozpoczął się w 2007 r. i ma charakter ideologiczny, jest dążenie sił muzułmańskich do zdobycia silniejszej pozycji w systemie politycznym oraz uzyskania przewagi w systemie społecznym. W 2014 r. spór ten nie miał charakteru gwałtownego, warto jednak zauważyć, że wcześniej - w latach 2010-2011 - mieliśmy do czynienia z kryzysem, w czasie którego pojawiły się akty przemocy. Co gorsza, obecnie aktorami konfliktu nie są już milicje wahhabickie skonfliktowane z rządem, ale - jak piszą niemieccy polemolodzy - islamistyczne bojówki, a konflikt przybrał postać kryzysu z odwołaniem się do przemocy. W 2014 r. - jak szacuje Instytut w Heidelbergu - kilkuset obywateli Bośni i Hercegowiny walczyło w Syrii, Iraku i Afganistanie. Do kraju wróciło około $50 \mathrm{z}$ nich. 29 kwietnia 2014 roku bośniacki parlament uchwalił ustawę, która stanowi, że udział w zagranicznych konfliktach zbrojnych lub działania na rzecz rekrutacji do obcych sił zbrojnych jest zagrożone karą do 10 lat pozbawienia wolności. Państwowa Agencja Informacji i Ochrony (Državna agencija za istrage i zaštitu, SIPA) przeprowadziła policyjną akcję o kryptonimie „Operacja Damaszek”, mającą na celu rozbicie grup, które finansowały i organizowały rekrutację bośniackich islamistów do walki za granicą. Operacja odbyła się w kilku miastach w dniu 3 września, a policja aresztowała 16 islamistów, w tym Huseina Bilal Bosnicia, lidera społeczności wahhabickiej w Krainie, podejrzanego o rekrutację bojowników do walk w Syrii i Iraku. W 2014 roku wahhabici zakupili kilka domów w miejscowości Bosanska Bojna (kanton Una Sana) w celu zorganizowania nowych wspólnot muzułmańskich. 13 listopada akcja SIPA została wznowiona, co doprowadziło do aresztowania jedenastu osób podejrzanych o terroryzm w Sarajewie oraz w innych miejscowościach Kakanj, Zenica, Maglaj i Živinice. W odpowiedzi na te działania, na islamistycznych stronach internetowych (np. „Esune” i „Put vjernika”) pojawiły się groźby pod adresem urzędników państwowych. 
kraju. Lokalni islamscy nauczyciele niejednokrotnie ganili obce wpływy w Bośni, które stanowią zagrożenie dla bośniackiej tożsamości narodowej ${ }^{53}$.

Przybysze dążą do zmiany tradycyjnego islamu w Bośni, a w szczególności zamierzają ograniczyć tradycyjne sposoby mieszania islamskich i nieislamskich tradycji w Bośni i Hercegowinie. Dla napływowych duchownych arabskich, wiele popularnych praktyk religijnych w Bośni i Hercegowinie jest zbyt podobnych do obrzędów chrześcijańskich, co zbliża bośniackich muzułmanów do Chorwatów i Serbów, a to jest - zdaniem muzułmańskich ortodoksów - nieakceptowalne. Dlatego też ich zamysłem jest „oczyszczenie” islamu w Bośni i w konsekwencji zdobycie decydującego wpływu na politykę i kwestie związane $\mathrm{z}$ bezpieczeństwem państwa ${ }^{54}$. Fundamentaliści zarzucają prominentnym członkom islamskiej społeczności, że nie pozwalają wahhabitom na integrację z muzułmańską społecznością Bośni, ani na budowanie własnej organizacji islamskiej jako alternatywnego rozwiązania.

W marcu 2006 roku piętnastu duchownych muzułmańskich prowadzących działalność misyjną w Bośni i Hercegowinie, absolwentów Wydziału Studiów Islamskich Uniwersytetu w Medynie w Arabii Saudyjskiej, wydało oświadczenie przeciwko tak zwanej idei takfir i jej upowszechnianiu. W powyższej deklaracji muzułmanie w Bośni i Hercegowinie są metaforycznie opisani jako „chorzy”, a nie bezpośrednio jako niewierni ${ }^{55}$. Zgodnie z tą deklaracją bośniacka wspólnota muzułmańska jest wspólnotą islamską, a nie społecznością niewiernych (kuffār ${ }^{56}$ ) lub grupą apostatów. Bezsprzecznie deklaracja ta jest jednym z najbardziej istotnych elementów w debacie o religii w Bośni z perspektywy polityki bezpieczeństwa.

${ }^{3}$ Na przykład w latach 1992-2001 roku, Arabia Saudyjska zebrała dwa miliardy riali, które przekazano Bośni i Hercegowinie. Pieniądze wydano na odbudowę meczetów, które zostały zniszczone lub uszkodzone w czasie wojny. Pod koniec 2006 zrekonstruowano ponad 500 meczetów, zbudowano 145 nowych, natomiast 147 przebudowano, 289 wciąż oczekuje na naprawę, w tym niektóre historycznie ważne meczety. Saudyjczycy nie tylko zapłacili za odbudowę wielu świątyń, ale także zainicjowali budowę ogromnych nowych obiektów sakralnych, które nie pasują do stylu i kultury bośniackiego islamu.

${ }^{54} \mathrm{~W}$ odpowiedzi na „medialną kampanię przeciwko wahhabitom i fundamentalistom w Bośni i Hercegowinie, Abdulmelik Basić, miejscowy współpracownik szejka Imada al-Misriego, pisał: „Ponieważ istnieje wiele nowych form naszej religijnej obrzędowości, które trudno wyplenić, dlatego niektórzy są wciąż skłonni uzasadniać swoje stanowisko interpretacją wywodzoną z hanafijskiej szkoły prawa islamskiego, a jeśli to nie wystarcza, to odwołują się do bośniackiego tradycyjnego lub nowoczesnego islamu. Bośniaccy tradycjonaliści próbują uciszyć każdego, kto sprzeciwia się takim nowym praktykom, zarzucając swym oponentom wahhabityzm. Jak długo takie złe praktyki będą możliwe, zależy od ludzi i ich zdolności do odkrywania tego, co jest prawdą, a co fałszem. Hanafi Mazhab jest czymś innym niż współczesna bośniacka obrzędowość islamska. Jeśli tradycja bośniacka jest ramą odniesienia, to każdy z nas powinien wiedzieć, co w obrzędowości naszych przodków (jeszcze przed epoką komunizmu) było niezgodne z naszą religią”. Basić dodatkowo ostrzegł o możliwości wybuchu wojny domowej w islamskiej społeczności w Bośni i Hercegowinie: „Jaki będzie efekt tego konfliktu w Bośni? Jakie będą jego skutki dla Europy i świata? Powinniśmy poważnie i odpowiedzialnie zapytać, czy [bośniaccy tradycjonaliści] chcą normalnych stosunków opartych na wzajemnym szacunku czy opowiadają się po stronie niesprawiedliwości i dyskryminacji, a tym samym podkładają ogień prowadzący do nowej fitny? W czyim interesie jest nowy Irak, Somalia, Afganistan, Liban? Wyznawcy ruchu sahwa nie uczynią żadnej krzywdy nikomu, jeśli nie zostaną zmuszenia do reagowania na zło, którego nie można tolerować ani dłużej usprawiedliwiać".

55 „Trzeba ich uzdrowić i ponownie skierować na prawowitą ścieżkę, a amputacja niektórych części ciała powinno być ostatecznością, a nie pierwszym krokiem" - ogłosili wówczas duchowni.

${ }^{56}$ Kafir (arab.: كافر -kāfir; w 1. mn. كفّار - kuffār) - w islamie niejednoznacznie rozumiany termin, thumaczony najczęściej jako „niewierny”. We wczesnośredniowiecznym języku arabskim, użytym w Koranie, wyraz ten określa osobę która ukrywa lub zaprzecza prawdzie (religijnej). 
Większość muzułmańskich misjonarzy w Bośni to studenci z Arabii Saudyjskiej. Niektórzy z nich byli członkami jednostki bojowej „El Mujahideen”, która wspierała zdominowaną przez Muzułmanów armię Bośni i Hercegowiny podczas wojny. Jak deklarują sami duchowni, impulsem do wydania wspomnianego oświadczenia była publiczna debata na temat takfiryzmu. Chodziło o to, aby w sposób jasny zakomunikować, że fundamentem społeczności muzułmańskiej na Bałkanach jest prawowity islam, nie idee ze świata niewiernych. Różne były reakcje na przywoływaną tu deklarację, która stała się przyczyną wyraźnego rozłamu we wspólnocie muzułmańskiej w BiH. Kluczową kwestią w tej dyskusji była islamska interpretacja wyrazu „Boszniak” jako pojęcia powszechnie stosowanego dla określenia identyfikacji narodowej Muzułmanów w Bośni i Hercegowinie. Czy Boszniacy są nadal wyznawcami islamu, czy też nie? Czy ich praktyki religijne są zgodne z prawem islamskim? Ostatecznie w wyniku ostrej debaty pojawiły się opinie, że Bośnia i Hercegowina jest jednak państwem niewiernych, w którym muzułmanie nie są ani bezpieczni, ani odpowiednio chronieni.

W poprzednich latach szejk Abu Anas es Shami działał jako muzułmański misjonarz w centralnej Bośni. Był jednym z głównych ideologów ruchu takfir Abu Musaba al-Zarqawiego i Abu Muhammeda al-Maqdisi'ego. Idea takfir była - przed powstaniem państwa Daesz - jednym z największych zagrożeń ze strony islamistów nie tylko dla Bośni, ale także dla bezpieczeństwa europejskiego. W rezultacie wielomiesięcznej debaty doszło do głębokiego konfliktu między islamskimi duchownymi z Arabii Saudyjskiej, którzy chcieli nawiązać współpracę ze wspólnotą muzułmańską reprezentowaną przez Cericia, a tymi, którzy odrzucili takie porozumienie ${ }^{57}$.

Innym przykładem antagonizmów wewnątrz świata muzułmańskiego w Bośni jest publiczny spór między Semirem Imamoviciem, redaktorem naczelnym czasopisma organizacji Młodzież Islamska „Staff” w Sarajewie, a Nedžadem Balkanem, nazywanym Ebu Muhamadem, islamskim misjonarzem w Wiedniu. Imamović opublikował artykuł zatytułowany Takfir od wiedeńskiej kuchni, na co Balkan odpowiedział, publikując bardzo szczegółową odpowiedź. W tym sporze postawy radykalne lub umiarkowane manifestowały się w odmiennym nastawieniu wobec osoby szejka Salmana al-Awdaha. Imamović był tłumaczem wykładu al-Awdaha w Sarajewie. Nedžad Balkan jednak twierdzi, że al-Awdah już nie zasługuje na szacunek po tym, jak saudyjski rząd uwolnił go z więzienia. Radykałowie zaczęli etykietować al-Awdaha oficjalnym duchownym rządu saudyjskiego. Grupa skupiona wokół Nedžada Balkana oraz inne ugrupowania (jak np. Kelimetul Haqq w Austrii) ogłosiły, że przywódcy islamskiej społeczności w Bośni i Hercegowinie nie są prawdziwymi wyznawcami Proroka.

Radykałowie, którzy aktywnie działają na Bałkanach (zwłaszcza w Sandżaku), ale też w wielu państwach europejskich ${ }^{58}$, głoszą, że ich aktywność jest adresowana do każdego, kto jest muzułmaninem i rozumie przesłanie w języku bośniackim, a nie wyłącznie do muzułmanów żyjących w Bośni i Hercegowinie.

${ }^{57}$ Do dziś funkcjonują zorganizowane grupy islamskich ,saudyjskich” misjonarzy w Europie publikujące w języku bośniackim (np. dzieła Abdullaha Azzama i Muhammeda Maqdisi’ego). Jest to np. Kelimetul Haqq. Zob. http://www.el-tewhid.com/author/portal-kelimetul-haqq

58 Warto wspomnieć o prominentnych bośniackich islamskich duchownych i aktywistach działających na terenie Austrii. Jeden z nich, Muhamed Porca, oświadczył, że nie ma możliwości prowadzenia negocjacji z tymi przedstawicielami muzułmańskiej społeczności, którzy współpracowali z komunistyczną służbą bezpieczeństwa 


\section{Islamizm a możliwość eskalacji przemocy na tle narodowościowym}

O fiasko budowy Bośni jako wielonarodowego państwa najczęściej obwinia się Serbów i Chorwatów, którzy bez wątpienia przyczynili się do tego niepowodzenia, częściowo przez swoje działania, ale głównie z powodu ,zewnętrznego przyciągania” ze strony sąsiednich państw. Zagrzeb zaoferował bośniackim Chorwatom schronienie w kraju będącym częścią zachodniej wspólnoty (dzięki integracji z NATO i UE), w którym - w przeciwieństwie do Bośni - osiągnięto stosunkowo wysoki poziom dobrobytu. Bośniaccy Serbowie są w innej sytuacji, gdyż wizja Serbii jako państwa nowoczesnego i bogatego oddala się ze względu na impas o charakterze politycznym, ekonomicznym i społecznym. Jednak Serbia była niegdyś silna gospodarczo, politycznie i militarnie, dlatego także dziś część serbskich obywateli Bośni marzy o zjednoczeniu bez względu na wszystko.

Istotne są także inne czynniki - poza gospodarką - wpływające na bośniackich Słowian. Bardzo ważna jest tu przeszłość, chodzi głównie o mocno osadzony w historii Bałkanów okres, gdy Imperium Osmańskie egzekwowało prawo szariatu.

Sharia nie dotyczy wyłącznie doktryny wiary czy praktyki religijnej, lecz obejmuje wszystkie aspekty życia oraz odnosi się zarówno do muzułmanów, jak i do wyznawców innych religii. Prawo szariatu definiuje islam jako wyznanie uprzywilejowane oraz - trzeba to jasno powiedzieć - wchodzące w konflikt z fundamentalnymi wartościami cywilizacji judeochrześcijańskiej opartej na jednostkowej koncepcji praw człowieka ${ }^{59}$, obejmującej wolność słowa i wyznania. W kulturze muzułmańskiej i prawie islamskim dyskusyjna jest na przykład kategoria równości wobec prawa: mężczyźni dominują nad kobietami, a muzułmanie mają więcej praw niż wyznawcy innych religii, którzy w żadnym razie nie mogą sprawować władzy nad muzułmanami ${ }^{60}$.

w Jugosławii. Nie można także - jego zdaniem - porozumieć się z przedstawicielami ruchów sufickich (różnorakich nurtów mistycznych w islamie) lub innymi grupami lub osobami, które nie przestrzegają prawdziwej doktryny i obrzędowości islamskiej. Na przestrzeni ostatnich kilkunastu lat w samej tylko Austrii pojawiły się liczne radykalne, bardzo aktywne ugrupowania islamistyczne, które były przeważnie powiązane z organizacjami humanitarnymi, np. Wysoki Komitet Saudyjski, pomagający muzułmanom w Bośni i Hercegowinie oraz Agencja Pomocy dla Trzeciego Świata. Działania tej grupy w Austrii i jej zwolenników w Bośni i Hercegowinie, a także Sandżaku, były jedną z głównych przyczyn konfliktów wewnątrzislamskich, które doprowadziły do zbrojnych starć w mieście Novi Pazar. W celu uniknięcia przejęcia niektórych meczetów w Sarajewie i innych miastach przez radykałów, liderzy oficjalnej wspólnoty muzułmańskiej w Bośni i Hercegowinie podjęli decyzję o zamknięciu kilku obiektów religijnych w 2007 roku.

59 Prawa człowieka są zachodnią koncepcją i na próżno doszukiwać się jej odpowiedników w tradycyjnych kulturach Wschodu czy Południa. Liberalna, zachodnia koncepcja praw człowieka jest ufundowana na indywidualizmie, natomiast w innych cywilizacjach człowiek jest ściślej związany z innymi ludźmi, a jaźń osobowa jest rozmyta w zbiorowości, z której jednostka czerpie główne elementy tożsamości. Z tych różnic wynika między innymi koncepcja ‘wartości azjatyckich' i krytyka Zachodu. Por. Ch. B rown, Prawa człowieka, [w:] J. Baylis, S. Smith (red.), Globalizacja polityki światowej, Kraków 2008, s. 853-874; E. C zi o m e r, Międzynarodowe aspekty ochrony praw człowieka, [w:] Zarys współczesnych stosunków międzynarodowych, Kraków 2000, s. 220-232; M. N ow i c ki, Co to sa prawa człowieka?, http://www.hfhrpol.waw.pl/pliki/MNowicki_CoToSa.pdf; W. Os i a y ń s k i, Przyszłość praw człowieka, https://opoka.org.pl/biblioteka/P/PS/przyszlosc_praw. html; E. St a d tmüller, Prawa człowieka i demokracja w stosunkach międzynarodowych, [w:] Z. C e s a r z, E. St a d t mü1le r, Problemy..., s. 286-302.

${ }^{60}$ A. ibn N a qib a l-M is ri, Reliance of the Traveller: A Classic Manual of Islamic Sacred Law, Beltsville, MD: Amana publications, 1994,0.? 25.3, p. 640. 
Pod rządami Turków wyznawcy religii niemuzułmańskich byli ,tolerowani” i cieszyli się relatywnie wysokim stopniem swobód. Mogli zachować własną wiarę, utrzymywać wspólnoty religijne oraz egzekwować własne prawa w ramach wspólnoty. Jednak katalog praw i wolności przysługujących ,niewiernym” był znacznie uboższy niż ten odnoszący się do wyznawców Proroka. W systemie określanym mianem dhimmitude ${ }^{61}$ obecność wyznawców innych religii była tolerowana dopóty, dopóki postępowali oni zgodnie z zasadami, a nieprzestrzeganie reguł oznaczało, że przestawali być chronieni i mogli stracić życie. Zatem kiedy dziś boszniaccy politycy mówią o wieloetnicznej tolerancji, to prawosławni i katolicy podejrzewają, że w istocie chodzi o restytucję systemu politycznego, w którym dominują muzułmanie. Żywe są obawy, że deklaracje przywódców muzułmańskich o ich zaangażowaniu na rzecz narodowej i religijnej różnorodności doprowadzą do sytuacji, w której wiele różnych grup etnicznych będzie pokojowo współistnieć, ale jednak pod panowaniem muzułmańskim i zgodnie z surowymi zasadami islamu.

Napięcia te istniałyby w pewnym stopniu, niezależnie od tego, jaka ideologia polityczna dominowałaby wśród Boszniaków. Muzułmanie wyobrażają sobie Bośnię jako niepodległe państwo, w którym będą dominować. Co prawda tylko nieliczni islamscy ekstremiści postulowali wydalenie niewiernych z kraju, ale jednak większość muzułmańskich przywódców uznała, iż w BiH tylko muzułmanie mogą cieszyć się pełnią praw obywatelskich. Głęboko religijni wyznawcy Allaha oparli swoje dążenia do dominacji na tradycyjnym przekonaniu, że rządy nie-muzułmanów nad muzułmanami są bluźnierstwem. Co więcej, spora część muzułmanów w Bośni to modelowi nacjonaliści, którzy - w przeszłości i obecnie - starają się wywalczyć jak najwięcej dla własnej grupy narodowościowej ${ }^{62}$. Islamiści mają najbardziej skrajne poglądy na temat relacji z ludnością innych wyznań. Widać to w wielu krajach i regionach świata - zwłaszcza opanowanych przez ISIS gdzie rozmaite ekstremalne grupy odpowiadają za niszczenie mienia, tortury, morderstwa oraz exodus „niewiernych” z terenów, gdzie żyli oni od 1,5 tysiąca lat.

Alija Izetbegović w fundamentalnej Deklaracji Islamskiej ${ }^{63}$ zajął wprawdzie umiarkowane stanowisko wobec wyznawców innych religii, ale jego propozycja nigdy nie satysfakcjonowała, ani tym bardziej nie zapewniała poczucia bezpieczeństwa Serbom i Chorwatom. Komunikat deklaracji jest bowiem bardzo prosty: muzułmanie powinni grać według reguł demokratycznych dopóty, dopóki nie będą wystarczająco silni, aby narzucić rządy islamskie, a gdy już nastanie państwo oparte na zasadach szariatu, wyznawcy innych religii będą mogli w nim funkcjonować jedynie jako ludność podporządkowana. Jeśli chrześcijanie porzuciliby własną organizację i wspólnotę religijną, to Izetbegović był gotów zaoferować im ,zrozumienie i współpracę"64.

${ }^{61}$ Współczesna muzułmańska odmowa praw mniejszościom jest zakorzeniona w historycznym odrzuceniu praw narodów niemuzułmańskich. Dhimmitude, termin ukuty przez historyka Bat Ye’ora, opisuje islamską praktykę odmawianie równości Żydom i chrześcijanom, którzy żyją pod rządami muzułmańskimi. http:// www.listyznaszegosadu.pl/powody-nieuznawania-izraela-tkwia-w-idei-dhimmi]. Patrz też hasło: MINORITIES: DHIMMIS, [w:] R. C. Martin (red.), Encyclopedia of Islam and the Muslim World, New York 2004, s. 451-452.

${ }^{62}$ A. D j il a s, The Nation that Wasn't, [w:] N. Mousavizadeh, (red.), The Black Book of Bosnia, New York: HarperCollins Publishers 1996, s. 25.

${ }^{63}$ A. Izetbeg o v c, The Islamic Declaration: A Programme for the Islamization of Muslims and the Muslim Peoples, Sarajevo, Bosnia, 1990.

${ }^{64}$ Deklaracja Islamska (Islamska deklaracja) o relacjach z nie muzułmanami-Muzutmanie w państwie nie-islamskim: * Mniejszości muzułmańskie w społeczności nieislamskiej, o ile jest im zagwarantowana swoboda 
Zaognienie tych sporów może doprowadzić do eskalacji przemocy i zwiększyć zagrożenie terroryzmem międzynarodowym w Bośni i Hercegowinie. Sytuacja w Bośni może nakręcić spiralę konfliktu, dlatego nadal niezbędne jest wsparcie świata zachodniego, pomoc zarówno o charakterze politycznym, jak i wojskowym, aby zapobiec takiemu rozwojowi wypadków. Zastanówmy się, jakie są potencjalne źródła przemocy prowadzącej do destabilizacji Bośni i Hercegowiny.

Tylko niewielka część analityków uważa, że jest możliwe odnowienie napięć międzyetnicznych prowadzących do takiego poziomu przemocy, z jakim mieliśmy do czynienia w latach 90. XX wieku. Niewielkie prawdopodobieństwo takiego scenariusza wynika chociażby z faktu, że skłonność (i realna możliwość) ze strony Serbii lub Chorwacji do podsycania wojny domowej lub bezpośredniej interwencji jest znacznie mniejsza niż dwie dekady temu.

Ponadto bośniackie siły zbrojne przeszły głęboką transformację. W 2006 roku armie trzech byłych walczących frakcji przekształcono w jednolite Siły Zbrojne Bośni i Hercegowiny pod cywilną kontrolą centralnego ministerstwa obrony. Siły zbrojne na terenie Bośni zostały także radykalnie zmniejszone. W opisywanym okresie armia bośniacka liczyła ok. 10 tys. żołnierzy zawodowych oraz ok. 5 tys. rezerwistów i 1 tys. pracowników cywilnych. Zgodnie z badaniami przeprowadzonymi w 2011 roku, realna liczebność sił zbrojnych wynosiła 8,5 tys. żołnierzy, z czego około 2 tys. pełni funkcje wartownicze (ważnych obiektów wojskowych, w tym składów broni i amunicji), natomiast siły rezerwy uznano w opisywanych badaniach za nieaktywne. Brak funduszy ogranicza możliwości dostosowania armii do standardów NATO oraz włączanie się w misje międzynarodowe Sojuszu Północnoatlantyckiego.

Siły Zbrojne BiH stanowią jednak niestety środowisko o wysokim stopniu polaryzacji politycznej. W 2011 roku przeprowadzono badania, z których wynika, iż odnotowano liczne przypadki oddziaływania ze strony liderów politycznych na oficerów i żołnierzy Sił Zbrojnych BiH. Odbywało się to na przykład w formie bezpośrednich apeli podczas publicznych wydarzeń, np. wieców o charakterze patriotycznym lub z okazji wizyt polityków z państw sąsiednich. Jednak niewielu obserwatorów wyraża przekonanie, że zintegrowana struktura dowodzenia armii bośniackiej może się załamać. Przeciwnie, obawy, że Siły Zbrojne BiH staną się źródłem niestabilności, są raczej rzadko wyrażane, uważa się raczej, że to armia może być ofiarą pogłębienia niestabilności politycznej.

W trakcie wojny (i tuż po jej zakończeniu) na terenie Bośni funkcjonowały oddzielne - dla każdej z trzech grup etnicznych - struktury tajnej policji, które ponoszą część odpowiedzialności za ówczesny chaos. Zostały one formalnie rozwiązane, a od 2004 roku ich funkcje przejęły jednostki Agencji Wywiadu i Bezpieczeństwa BiH (OSA, Obavje-

praktykowania własnej religii, aby żyć i rozwijać się, pozostają lojalni i muszą spełniać wszelkie zobowiązania wobec tej społeczności z wyjątkiem tych, które szkodzą islamowi i muzułmanom * Pozycja muzułmańskich mniejszości zawsze będzie realnie uzależniona od siły międzynarodowej społeczności islamskiej i szacunku, którym ta społeczność cieszy się w świecie (s. 50). Mniejszości niemuzutmańskie w państwie islamskim: * Mniejszości niemuzułmańskie w państwie islamskim, pod warunkiem, że pozostają lojalne, korzystają z wolności religijnej i wszelkiej ochrony; * Dokonujemy odzróżnienia między chrześcijańskim nauczaniem a Kościołem. To pierwsze uważamy za wyraz słowa bożego, choć w niektórych punktach zniekształconego, natomiast organizacja [religijna] (...) stała się nie tylko nieislamska, ale antychrześcijańska * Jeśli chrześcijanie będą sobie tego życzyć, w przyszłości możemy stać się przykładem zrozumienia i współpracy między dwoma wielkimi religiami dla dobra ludzi i ludzkości. Zob. http://www.angelfire.com/dc/mbooks/Alija-Izetbegovic-Islamic-Declaration1990-Azam-dot-com.pdf [dostęp: 2016-10-03]. 
štajno-sigurnosne agencije Bosne i Hercegovine). Zadaniem Agencji jest gromadzenie informacji wywiadowczych w celu ochrony bezpieczeństwa, integralności terytorialnej i porządku konstytucyjnego Bośni i Hercegowiny. Należy docenić fakt, że w obecnych bośniackich służbach wywiadowczych obowiązują (i są respektowane) wysokie standardy etyki zawodowej, a jej funkcjonariusze - i wywiad jako taki - cieszą się wysokim poziomem niezależności politycznej. Niestety OSA musi dzielić się zadaniami w dziedzinie prowadzenia walki z terroryzmem ${ }^{65}$ i zorganizowaną przestępczością ze strukturami regularnej policji państwowej i bośniackim wymiarem sprawiedliwości, które pozostają bardziej podatne na naciski polityczne, a także korupcję. Zwalczanie terroryzmu w każdej formie, bez względu na motywacje religijne czy polityczne sprawców, stanowi element racji stanu każdego państwa. Ale w przypadku Bośni - kraju niestabilnego, podzielonego wewnętrznie i narażonego na obce wpływy - potencjalne uwikłanie w politykę resortów siłowych może stanowić szczególne zagrożenie dla istnienia państwa ${ }^{66}$.

\section{Islam w BiH w perspektywie międzynarodowej}

Wpływy islamistów w Bośni są kluczem do osiągnięcia publicznie deklarowanego celu: utworzenia globalnego kalifatu. Kiedy o tym mówiono jeszcze kilkanaście lat temu, to mieszkańcy Zachodu - do czasu utworzenia Państwa Islamskiego - byli raczej skonsternowani i traktowali tego rodzaju manifesty jako niezrozumiałe, a nawet śmieszne. Tymczasem dla mieszkańców Bałkanów cele polityczne islamistów nie są abstrakcją, lecz realnym zagrożeniem. Są one postrzegane jako niebezpieczne nie tylko dlatego, że ich adresatami są również umiarkowani muzułmanie, ale dlatego, że zyskują wsparcie ważnych graczy na arenie międzynarodowej, a mianowicie Turcji, Organizacji Współpracy Islamskiej, a także ISIS.

\section{Turecka ofensywa kulturowa i polityczna na Bałkanach}

Państwo przypominające pod pewnymi względami islamski kalifat istniało w ramach Imperium Osmańskiego. O wielkim znaczeniu Bośni dla Turcji wiemy, odkąd Ankara przystąpiła do misji pokojowych ONZ w latach 90. XX wieku. Po ustaniu działań wojen-

${ }^{65}$ Dlatego, pomimo faktu, iż Bośnia dokonała ogólnego postępu w walce z terroryzmem, zdarzają się spektakularne porażki, jak na przykład tajemnicze zniknięcie z więzienia znanego terrorysty Karaya Kamela bin Alego, znanego jako Abu Hamza. Por. Mark L ow e n, Major Criminal Flees Bosnia Jail, BBC, July 29, 2009; a także: Anes Alic, The Ringleaders of the Bosnia-Herzegovina Wahhabi Movement, „,The Jamestown Foundation Terrorism Focus", Vol. 4, Issue 6, March 23, 2007.

${ }^{66}$ A zatem sąsiedzi Bośni oraz jej resorty siłowe nie stanowią bezpośredniego źródła niestabilności. Nie oznacza to jednak, że nie istnieją inne niebezpieczeństwa. Istnieje bowiem prawdopodobieństwo pojawienia się aktów przemocy o niskim stopniu natężenia. Przemoc tego rodzaju może odpowiadać podziałom etnicznym i narodowościowym. Osoby, które mogą stać się sprawcami lub ofiarami aktów przemocy, to członkowie różnych grup, jak np. pseudokibice, funkcjonariusze sił specjalnych oraz weterani wojskowi i wywiadu, obecnie zatrudniani przez prywatne firmy ochroniarskie, ale także osoby obecnie zatrudnione w policji i sądownictwie dwóch kluczowych instytucjach, w których reformy zmierzające do wykreowania etosu służby ufundowanego na zasadach profesjonalizmu i bezstronności pozostają niezrealizowane. Taka przemoc, np. w formie krótkiego konfliktu, może jednak okazać się katastrofalna dla praworządnych obywateli. 
nych turecka armia ustanowiła swą siedzibę w Zenicy i przyłączyła się do misji IFOR / SFOR, a następnie oddziały tureckie - w naturalny sposób - stały się częścią kolejnej misji EUFOR, w ramach której Ankara dostarczyła drugiego co do wielkości kontyngentu wojskowego. W późniejszych latach Turcy wykorzystali swoją siłę ekonomiczną do zwiększenia wpływów na Bałkanach, a poziom obrotów handlowych firm znad Bosforu z krajami bałkańskimi wzrósł bardzo wyraźnie, podobnie jak wielkość tureckich inwestycji w Bośni.

Nie można nie doceniać roli tureckiej ofensywy w wymiarze „soft power”. To nie tylko ogromna popularność (nie tylko zresztą na Bałkanach) tureckiej muzyki czy produkcji telewizyjnej, ale także spektakularne inwestycje w sferę kultury. Turcy zbudowali największy kampus uniwersytecki na Bałkanach - w dzielnicy Ilidza na przedmieściach Sarajewa ${ }^{67}$. Działania te są bardzo spektakularne ze względu na niewielką dynamikę wzrostu inwestycji z Europy i Stanów Zjednoczonych. Trzeba też oddać sprawiedliwość tureckim dyplomatom, którzy wykonali ogromną pracę na rzecz pojednania wśród narodów bałkańskich.

Pojednanie w regionie Bałkanów oraz ich rozwój gospodarczy, a zwłaszcza odbudowa więzi kulturowych pod patronatem Turcji, to szlachetne i głośno promowane cele polityki zagranicznej Ankary, które cieszą się uznaniem wielu grup etnicznych i narodowościowych ${ }^{68}$. Jednak bardziej prawdopodobne jest to, że powszechnie znana nostalgia za Imperium Osmańskim - charakterystyczna zwłaszcza dla Recepa Tayyipa Erdoğana czy niegdysiejszego ministra spraw zagranicznych Ahmeta Davutoglu - wywołuje obawy wśród nie-muzułmańskich mieszkańców Bałkanów ${ }^{69}$. Dobrym przykładem jest spór sprowokowany przez przemówienie wygłoszone przez Davutoglu w 2009 roku podczas sarajewskiej konferencji na temat „Osmańskiego dziedzictwa i wspólnot muzułmańskich na współczesnych Bałkanach”. Jego wystąpienie było niejednoznaczne. Polityk ogłosił, że nadszedł czas na ponowne zjednoczenie w formie uporządkowania własności w regionie, poprzez odbudowanie wielokulturowego współistnienia, a także poprzez utworzenie nowej strefy ekonomicznej ${ }^{70}$. Wprawdzie referent nie określił wprost, co rozumie pod hasłem ,ponownego zjednoczenia”, ani tego, kim ma być beneficjent własności, jednak nie było wątpliwości a autor wypowiedzi nie dementował - że rolą Turcji jest dominacja w regionie. Dla tych Bośniaków, którzy interpretują uwagi tureckiego ministra w kontekście historycznym, jego wezwanie do „wielokulturowego współistnienia” mogło zostać zinterpretowane jako odniesienie do osmańskiego systemu dhimmitude. Podobnie umieszczenie deklaracji Davutoglu w kontekście współczesnym budzi sprzeciw wielu odbiorców, którzy zwracają uwagę na pogarszającą się obecnie sytuację chrześcijan w coraz bardziej ,islamistycznej” Turcji ${ }^{71}$.

Jeszcze niedawno wydawało się mało prawdopodobne, aby turecki „,neo-ottomanizm” był realnym zagrożeniem dla Bośni. Amerykańska ambasada w Ankarze scharakteryzowała Turcję - używając metafory, jako kraj o ,ambicjach klasy Rolls Royce, ale parametrach Rovera"72. Jednak wydaje się, że obecnie, po wielkim wzmocnieniu Turcji na arenie międzynarodowej (wojna w Syrii, kryzys uchodźców, nieoczekiwany zwrot w relacjach z Ro-

${ }^{67}$ Anes A 1 ic, Turkey's Growing Influence in the Balkans, oilprice.com, June 9, 2010.

${ }^{68}$ D. S toja novic, Turkey Uses Economic Clout to Gain Balkan Foothold, ,The Seattle Times”, March 13,2011 .

69 Zob. I ze tb e g o vi ć, Islamic Declaration, s. 14.

70 E. He c i mović, Sta Turska hoce na Balkanu?, „Dani”, October 23,2009.

71 J. Eibne r, Turkey's Christians Under Siege, „Middle East Quarterly”, Vol. 18, No. 2, Spring 2011.

72 What Lies Beneath Ankara's New Foreign Policy, State Department cable Ankara 87, November 29, 2010. 
sją itd.) oraz konsolidacji autorytarnej władzy Erdoğana (po pacyfikacji nieudanego zamachu i spektakularnej pacyfikacji struktur ruchu Hizmet Fethullaha Gülena) sytuacja uległa zasadniczej zmianie, a oceny dyplomatów amerykańskich są nietrafne. Dlatego też wątek osmańskiego odrodzenia pozostaje aktualny i wywołuje spore emocje na Bałkanach. Gdyby przywódcy Boszniaków byli autentycznie zaangażowani w proces pojednania narodów Bośni, to zapewne znaleźliby skuteczny sposób, aby dyplomatycznie złagodzić lub nawet odrzucić deklaracje zwolenników nowej tureckiej dominacji na Bałkanach ${ }^{73}$.

\section{Bośnia i Hercegowina w świecie islamu}

Oprócz dwustronnych relacji z Turcją, Arabią Saudyjską i Iranem, Bośnia i Hercegowina ma status obserwatora (od 1994 roku) w Organizacji Współpracy Islamskiej (OIC), międzynarodowej organizacji reprezentującej 56 krajów muzułmańskich oraz Autonomię Palestyńską. Arabia Saudyjska zapewnia najwięcej środków na funkcjonowanie tej organizacji, natomiast Iran, Pakistan, Malezja, Indonezja, Turcja są czołowymi jej członkami. Chociaż OWI nie jest organizacją islamistyczną, to ma jednak charakter polityczno-religijny, gdyż jej zasadniczym celem jest umacnianie islamu w świecie i działanie dla dobra mniejszości muzułmańskich w krajach nieislamskich. Organizacja ta - jak przekonuje część obserwatorów - podziela wizję globalnego kalifatu, którego celem jest wdrożenie prawa szariatu. Niektórzy jej członkowie twierdzą nawet, że OWI obecnie stanowi swoiste wcielenie prawa islamskiego. Od czasu do czasu członkowie organizacji wchodzą w spory z Bractwem Muzułmańskim, ale mimo to obydwie instytucje współpracują dla realizacji wspólnych zadań.

W kwietniu 2013 roku w czasie wizyty w Sarajewie sekretarz generalny Organizacji Współpracy Islamskiej, Ekmeleddin Ihsanoglu, wezwał BiH do przyjęcia pełnego członkostwa w organizacji. Bakir Izetbegović zasugerował zaś, że pełne członkostwo byłoby korzystne dla Bośni, dając jej dostęp do funduszy rozwojowych ${ }^{74}$. Bośnia i Hercegowina musiałaby jednak ratyfikować wszelkie istniejące umowy i konwencje w ramach organizacji, w tym islamską Deklarację Kairska o Prawach Człowieka z 1990 roku5, a dokument ten wyklucza jakiekolwiek prawa niezgodne z Koranem, co sprawia, że pojawia się sprzeczność z zachodnim systemem praw człowieka, obejmującym takie prawa i wolności, jak równość wyznań religijnych czy wolność słowa, w tym prawo do krytyki islamu.

Organizacja Współpracy Islamskiej potwierdza założenia Deklaracji Kairskiej za pomocą corocznych raportów na temat islamofobii w krajach zachodnich, mających podobny charakter jak sprawozdania na temat Bośni, rozpowszechniane przez lokalną Wspólnotę Islamską. Członkostwo Bośni w OWI prawdopodobnie wzmocni monitoring aktów werbalnych i działań wymierzonych przeciwko muzułmanom w BiH, co może sprawić, że coraz trudniej będzie krytykować politykę ekstremalnych grup islamistycznych w tym kraju. OWI wykazuje aktywne zainteresowanie transformacją wewnętrzną Bośni, czego dowodem jest odtworzenie Grupy Kontaktowej ds. Bośni z początku lat $90 .^{76}$ Istnieje

73 P. Go o d e nough, OIC Fulfills Function of Caliphate, Embodies 'Islamic Solidarity, 'Says OIC Chief, CNS News, May 10, 2010.

${ }^{74}$ K. E fen d i c, OIC Invites Bosnia to Become Full Member, Balkan Insight, April 16, 2013.

75 www.oicun.org/articles/54/1/CairoDeclaration-on-Human-Rights-in-Islam/1.html.

76 Turkey Trying to Keep Its Influence in Bosnia, State Department cable Ankara 1651, November 17,2009. 
zatem niewielka szansa, że Organizacja Współpracy Islamskiej będzie neutralna wobec sporów między Boszniakami a bośniackimi Serbami i Chorwatami.

Agitację na rzecz pełnego członkostwa w OWI trudno uznać za działanie mające na celu poprawę stosunków między grupami narodowościowymi i religijnymi w Bośni. Być może Serbowie i Chorwaci wyolbrzymiają zagrożenie islamizmem (lub potencjalną dominacją islamu), ale trudno nie zauważyć, że niektóre posunięcia i deklaracje ze strony liderów boszniackich niewątpliwie dostarczają mocnych argumentów w sporze politycznym i ideologicznym.

\section{Muzułmańska Bośnia i Hercegowina a świat zachodni}

Konflikt w Bośni i Hercegowinie nie zakończył się wraz z podpisaniem porozumienia z Dayton w dniu 14 grudnia 1995. Wkrótce potem Coordination Council for Humanitarian Agencies (CCHA) w Bośni i Hercegowinie ogłosiła nowy cel - wspieranie edukacji muzułmańskiej jako części procesu budowania narodu bośniackiego ${ }^{77}$. Ponieważ wielu członkom CCHA zarzucano powiązania z ekstremistami, w latach 2002-2004 miała miejsce międzynarodowa interwencja przeciwko wielu islamskim organizacjom humanitarnym i misyjnym. W przypadku niektórych ugrupowań samorządy działały zgodnie z rekomendacjami USA, i - co więcej - nawet Arabia Saudyjska dołączyła do Stanów Zjednoczonych w działaniach przeciwko pewnym organizacjom i osobom w Bośni i Hercegowinie.

Istotna debata w Bośni i Hercegowinie dotyczyła kwestii reformy politycznej jako warunku wstępnego wprowadzenia nowej konstytucji. Jako religijny i narodowy przywódca Boszniaków, Cerić w swoich publicznych wypowiedziach wspierał prawo muzułmanów w BiH do posiadania własnego państwa narodowego. Propagowanie tego postulatu wywołało ostre reakcje ze strony bośniackich Serbów i międzynarodowych przedstawicieli w Bośni i Hercegowinie. Na przykład Biuro Wysokiego Przedstawiciela w Bośni i Hercegowinie (OHR) zareagowało na wystąpienie Cericia w Bośniackim Centrum Islamskim w Detroit. Wezwano wówczas Cericia do powstrzymania się od wygłaszania oświadczeń politycznych, które prowadzą do naruszenia porozumienia pokojowego z Dayton i powodują niestabilność polityczną ${ }^{78}$.

Debaty o przyszłości politycznej i konstytucyjnej w Bośni i Hercegowinie determinują przyszły rozwój wielu nierozwiązanych kwestii. Możliwa jest - niestety - dalsza islamizacja boszniackiej wspólnoty narodowej i jej tożsamości. Duchowi i narodowi przywódcy muzułmanów konsolidują swoje wpływy polityczne, odwołując się do tożsamości religijnej, którą łączą z kwestią narodową, przyczyniając się tym samym do dalszej dezintegracji etnicznej

77 W swoim raporcie za 1995 r. CCHA stwierdziła, że „edukacja stanowi kluczowy element zainteresowania międzynarodowych organizacji zarówno islamskich, jak i nieislamskich w Bośni i Hercegowinie, ze względu na jej znaczenie dla budowania narodu".

${ }^{78} \mathrm{~W}$ dokumencie tym czytamy m.in.: „Mandat Wysokiego Przedstawiciela polega na ochronie układu pokojowego z Dayton. Bośnia i Hercegowina jest krajem wszystkich swoich obywateli, wspólnoty, która obejmuje Serbów, Chorwatów, Boszniaków i innych. Umowa pokojowa z Dayton chroni prawa wszystkich narodów i obywateli, natomiast Cerić nie ma prawa domagać się zmiany tego stanu rzeczy. Możliwe są zmiany w zapisach porozumienia pokojowego z Dayton tylko za pośrednictwem procedur przewidzianych w Konstytucji. System polityczny i prawny Bośni i Hercegowiny nie mogą być zorganizowane ze szkodą dla kogokolwiek”. 
w Bośni i Hercegowinie. Prawdopodobnie przynajmniej niektórzy liderzy islamscy oraz prowadzone przez nich ugrupowania oczekują czegoś na kształt „,nowego dżihadu”. Równocześnie mamy do czynienia z wewnętrznymi konfliktami między różnymi ugrupowaniami muzułmańskimi. Jest to zatem proces dwukierunkowy. Kwestia tożsamości Boszniaków jako muzułmanów jest - i będzie nadal - głównym polem bitwy o przyszłość polityczną, społeczną i kulturową Bośni i Hercegowiny. W ciągu ostatnich 20 lat amalgamat różnorodnych doktryn i orientacji licznych grup islamskich oddziaływał - i nadal oddziałuje - na przekształcanie religijnych i narodowych tożsamości muzułmanów. W przyszłości okaże się też, jakie impulsy zewnętrzne i do jakiego stopnia ukształtują Bośnię XXI wieku.

Wiele lat po zakończeniu walk w Bośni i Hercegowinie, jej integralność terytorialna i stabilność wewnętrzna nie są ostatecznie utrwalone. Bezsprzecznie członkostwo w Organizacji Traktatu Północnoatlantyckiego i Unii Europejskiej wzmocniłoby bezpieczeństwo w Bośni i Hercegowinie. Chociaż inne kraje bałkańskie z powodzeniem dołączyły do obydwu wymienionych organizacji, to raczej mało prawdopodobne, aby integracyjny scenariusz spełnił się w najbliższym czasie w przypadku Sarajewa, ponieważ dotychczasowe reformy, które miały utorować drogę do członkostwa w NATO i UE, utknęły w martwym punkcie, jedność państwa jest wątpliwa, jego struktura rządowa nieefektywna, a gospodarka pozostaje ciągle w złym stanie.

Bośniackie rozwiązania ustrojowe - zaprojektowane w ramach porozumień pokojowych z Dayton - prowadzą do słabości władzy centralnej, administracja państwowa jest nieefektywna, pojawiają się trudności w zarządzaniu krajem, a złożona struktura państwa ${ }^{79}$ wywołuje spory i napięcia motywowane względami etnicznymi ${ }^{80}$.

Gdyby gospodarka Bośni prosperowała, to prawdopodobnie napięcia wewnętrzne byłyby - stopniowo - coraz słabsze. Niestety podstawowe wymagania rozwojowe gospodarki (zwłaszcza infrastrukturalne, takie jak projekty energetyczne) są często blokowane przez brak współpracy między jednostkami administracyjnymi kraju ${ }^{81}$. Ponadto liberalizacja ekonomiczna, konieczna dla wzrostu gospodarczego, pozbawiłaby wiele warstw biurokracji znacznych dochodów, czy to z kontroli przedsiębiorstw państwowych, które wywodzą się jeszcze z socjalistycznej Jugosławii, a także przychodów z mnóstwa istniejących przepisów i wymogów administracyjnych.

Silne przywództwo mogłoby przezwyciężyć inercję państwa, a silne przywództwo jest właśnie tym, czego w Bośni brakuje. Tymczasem korupcja jest powszechna ${ }^{82}$, przeciętny mieszkaniec Bośni zmaga się z wysokim bezrobociem, sięgającym nawet 57 pro-

${ }^{79}$ Państwo składa się z dwóch podmiotów - Federacji Bośni i Hercegowiny oraz Republiki Serbskiej. Na wspólnym terenie obydwu tych części leży dystrykt Brczko, pozostający pod kontrolą międzynarodową. Federacja jest podzielona na 10 względnie autonomicznych kantonów, co z grubsza odzwierciedla podziały terytorialne między Boszniakami, Serbami i Chorwatami.

${ }^{80}$ Prawdopodobnie tylko administracja amerykańska nie dostrzega, że ów kłopotliwy mechanizm koegzystencji dwóch podmiotów i słabego rządu centralnego, który przyjęto w Dayton w 1995 r., po prostu nie działa. Zob. http://sarajevo.usembassy.gov/speech_20130703.html [12/21/2016].

${ }^{81}$ L. P a s i c, Sources of Energy in Bosnia and Herzegovina, and Implications for Energy Security, Balkananalysis.com, 9 maja 2011, http://www.balkanalysis.com/bosnia/2011/05/09/sources-of-energy-in-bosnia-andherzegovina-and-implications-for-energy-security/ [12/21/2016].

${ }^{82}$ B. Divj a k; M. P u g h, The Political Economy of Corruption in Bosnia and Herzegovina, International Peacekeeping, Vol. 15, No. 3, June 2008, s. 373-386. https://www.researchgate.net/publication/248953854_The Political_Economy_of_Corruption_in_Bosnia_and_Herzegovina [12/21/2016]. 
cent wśród młodych ludzi ${ }^{83}$. Skutki ubóstwa są przez czarny rynek pracy oraz rozległe dotacje państwowe nieco łagodzone, co jednak dodatkowo obciąża gospodarkę.

Nie udało się zrealizować scenariusza dezintegracji kraju w wyniku działań wojennych $^{84}$, ale podział Bośni od wewnątrz jest zaawansowany i dokonuje się w zawrotnym tempie. Nie tylko słabość gospodarki przyczynia się do tego procesu. Mamy do czynienia ze świadomą polityką alienacji, prowadzoną przez wszystkie trzy grupy narodowościowe. Całe pokolenie mieszkańców Bośni wychowało się w narodowościowo podzielonym systemie oświaty, w którym każda grupa ma własną wersję nauczania religii, geografii, historii i języka ${ }^{85}$, a segregacja ta jest dodatkowo utrwalana przez polityków, cynicznie wykorzystujących lęki i napięcia narodowościowe.

Nic dziwnego, że pojednanie między grupami etnicznymi, które było wielką nadzieją w Dayton, nie jest łatwe. Przeciwnie, zdecydowana większość bośniackich Serbów wspiera secesję Republiki Serbskiej. Duża liczba Chorwatów już opuściła kraj: szacuje się, że obecnie stanowią oni jedynie 10 proc. populacji Bośni, w porównaniu z 17 proc. w 1991 roku $^{86}$. Należy nadmienić, że spośród tych Chorwatów, którzy nadal pozostają w kraju, ponad 40 proc. chce wykroić własny, chorwacki podmiot z Federacji ${ }^{87}$, pomimo faktu, że system kwot Dayton obecnie daje im nadreprezentatywny wpływ na sprawy państwowe ${ }^{88}$.

Większość mieszkańców kraju „nie uważa, że Bośnia i Hercegowina jest ich »ojczyzną «" zmierza w niewłaściwym kierunku ${ }^{90}$, a 77 proc. ludzi młodych twierdzi, że opuściłoby $\mathrm{BiH}$, gdyby tylko pojawiła się taka możliwość ${ }^{91}$. Takie negatywne postrzeganie jest typowe dla krajów dotkniętych kryzysem demograficznym, tak jak dzisiejsza Bośnia i Hercegowina, która znajduje się w połowie rankingu państw zagrożonych i niewątpliwie znajduje się w poważnych kłopotach ${ }^{92}$.

Ani NATO, ani UE nie rozwiążą tych problemów ${ }^{93}$. Bośnia i Hercegowina spełniła wszystkie wymogi członkostwa w NATO, z wyjątkiem rejestracji obiektów obronnych

83 Improving Opportunities for Young People in Bosnia Herzegovina, World Bank, 14 lutego 2013 r. http:// www.worldbank.org/en/news/feature/2013/02/14/improving-opportunities-young-people-Bosnia-Herzegovina [12/21/2016].

${ }^{84}$ Jak powszechnie wiadomo, byli prezydenci Serbii i Chorwacji - Slobodan Milošević i Franjo Tudjman - projektowali rozbiór Bośni, szkicując ów podział na kawiarnianej serwetce w 1991 roku.

${ }^{85}$ A. K a m b e r, Segregated Bosnian Schools Reinforce Ethnic Division, Institute for War \& Peace Reporting, May 3,2011. https://iwpr.net/global-voices/segregated-bosnian-schools-reinforce-ethnic-division [12/21/2016].

${ }^{86}$ M. A bra mow it z; J. H o o pe r, The Death of the Bosnian State, The National Interest, July 20, 2011. Zob. http://nationalinterest.org/commentary/the-death-the-bosnian-state-5631 [Dostęp: 2016/12/21].

${ }^{87}$ Focus on Bosnia Herzegovina, Gallup Balkan Monitor, GMB Focus on \#04, November 2010.

${ }^{88} 1 / 3$ stanowisk państwowych na poziomie centralnym i połowę z nich w rządzie Federacji.

${ }^{89}$ A. Alić, V. Sk oc aj ić, Understanding Bosnia, Part One, ISN Security Watch, February 26, 2009. http://www.strategicstudiesinstitute.army.mil/files/SSI-pub-1206.epub [12/21/2016].

${ }^{0}$ Public Opinion Poll, Bosnia and Herzegovina, BiH, August 2010, Washington, DC: National Democratic Institute, s. 5. https://www.ndi.org/files/NDI_Bosnia_Poll_Report_August_2010.pdf [12/21/2016].

${ }_{91}$ Independent Evaluation of the National Youth Policy in Bosnia-Herzegovina, ONZ, Sarajewo, 29 kwietnia 2005 r., http://www.un.org/esa/socdev/unyin/documents/wpaysubmissions/bosnia.pdf [12/21/2016].

${ }_{92}$ Zob.: Fragile States Index. http://fsi.fundforpeace.org/rankings-2015.

${ }^{3}$ NATO jako pierwsze wprowadziło Siły Implementacyjne (IFOR), a potem kolejną misję - Siły Stabilizacyjne (SFOR), w celu utrzymania stabilności 9 lat po wojnie. Zadaniem obecności wojskowej NATO w Sarajewie było wspieranie Bośni na ścieżce reform i zobowiązań związanych z przystąpieniem do Sojuszu. 
uznanych za niezbędne dla przyszłej obrony jako własności państwa centralnego ${ }^{94}$. Oczywiście istnieją pewne przeszkody na drodze do przystąpienia do Sojuszu ${ }^{95}$, mają one charakter polityczny, a więc mogą zostać usunięte przez elity i obywateli państwa. Ale nawet jeśli bariery akcesji zostaną usunięte, to NATO nie dysponuje środkami, aby rozwiązać poważne problemy społeczne i ekonomiczne Bośni.

Przystąpienie do UE, które wymaga wprowadzenia szeroko zakrojonych reform gospodarczych, społecznych i politycznych, jest często postrzegane przez polityków zachodnich jako środek krytyczny integracji euroatlantyckiej. Jednak proces integracyjny jest mało skutecznym narzędziem usprawniania rządów i ograniczenia nieefektywnego sektora państwowego, promowania przedsiębiorczości, redystrybucji dóbr czy rozwiązywania napięć kulturowych między różnymi grupami. Niemniej jednak to właśnie Unia skłoniła władze Bośni, między innymi, do wzmocnienia centralnych instytucji państwowych, reformy administracji publicznej i systemu sądownictwa, walki z korupcją i rozwoju gospodarki rynkowej, choć zmiany te zakończyły się ograniczonym sukcesem. Dziś urzędnicy Wspólnoty twierdzą, że nie mogą zbyt wiele uczynić dla rozwiązania problemów BiH, zwłaszcza w sytuacji braku po stronie bośniackich polityków klarownej wizji przyszłości i zakończenia sporów wewnętrznych ${ }^{96}$. Decydenci unijni odpowiedzialni za proces integracji ostrzegli, że jeśli obecna sytuacja będzie się powtarzać, wstąpienie BiH w struktury UE może zostać „zamrożone"97. Jeśli Bośnia i Hercegowina byłaby tylko kolejnym kandydatem do UE, taka ocena sytuacji nie przyciągnęłaby zbyt dużej uwagi społeczności międzynarodowej. Ale w przypadku Sarajewa jest inaczej, ze względu na ogromny wysiłek Europy i jej działania na rzecz odbudowy Bośni i Hercegowiny ${ }^{98}$. Niepowodzenie ambitnych planów wyjaśnia, dlaczego Europejczycy twierdzą obecnie, że głównie do Boszniaków, a nie podmiotów zewnętrznych, należy rozwiązywanie problemów Bośni i Hercegowiny.

94 Ale trzeba nadmienić, że Republika Serbska odmówiła przeniesienia swej własności na państwo centralne, a jej prezydent, Milorad Dodik, wezwał do demilitaryzacji państwa, zamiast przystąpienia do NATO. Zob. NATO's Relations with Bosnia and Herzegovina, http:/www.nato.int/cps/en/natohq/topics_49127.htm?selectedLocale=uk [12/21/2016], a także: Relations with Bosnia and Herzegovina, http://www.nato.int/cps/en/natolive/ topics_49127.htm [12/21/2016].

95 S. Wo e hrel, Bosnia and Herzegovina: Current Issues and U.S. Policy, Congressional Research Service, (CRS) Report R40479, Washington, DC: CRS, 24 stycznia 2013 r., https://fas.org/sgp/crs/row/R40479. pdf $[12 / 21 / 2016]$.

96 Bosnia and Herzegovina 2012 Progress Report, European Commission SWD (2012) 335 Final, Brussels, Belgium, 10 października 2012 r., s. 4-5. http://ec.europa.eu/neighbourhood-enlargement/sites/near/files/pdf/ key_documents/2012/package/ba_rapport_2012_en.pdf [12/21/2016].

${ }_{97}$ Bosnia's Human Rights Record Hinders EU talks. EurAktiv.com, 24 maja 2013 r., http://www.euractiv. $\mathrm{com} /$ section/enlargement/news/bosnia-s-human-rights-record-hinders-eu-talks/ [2016-12-21].

98 UE zastąpiła bowiem siły SFOR z własną operacją wojskową European Union Force (EUFOR); zastąpiła także misję policyjną ONZ misją European Union Police Mission, a przez pewien czas połączono stanowisko specjalnego przedstawiciela UE w Bośni i Hercegowinie z biurem ONZ Wysokiego Przedstawiciela ONZ (Office of the High Representative) w celu koordynowania i bezpośredniego angażowania społeczności międzynarodowej w sytuację w Bośni. 


\section{Zakończenie}

Niektórzy muzułmańscy duchowni często odwołują się do analogii historycznej, porównując współczesną Bośnię do średniowiecznej Andaluzji, którą do upadku doprowadziła rekonkwista i prześladowania muzułmanów ze strony chrześcijan. Autorzy tych komparacji nie chcą jednak pamiętać, iż kulturę tolerancji „ozdoby świata” 99 przez kilka stuleci tworzyli muzułmanie, żydzi oraz - wywodząca się jeszcze z państwa Wizygotów - większość chrześcijańska, a arabskie dynastie panujące w prowincji włączyły wiele nieislamskich elementów kulturowych w obręb własnego państwa. Upadek Andaluzji to kompletnie nietrafna - a w sensie normatywnym szkodliwa - rama interpretacji współczesnej sytuacji muzułmanów na Bałkanach. Twórcza, dynamiczna, wielokulturowa cywilizacja muzułmańska w Hiszpanii powinna stanowić raczej symboliczny wzorzec rozwojowy dla BiH i całego regionu w przyszłości. Należy też pamiętać, że tak jak do upadku Kalifatu Kordoby i, szerzej, destrukcji kultury i cywilizacji, islamskiej nauki i humanizmu przyczyniły się najazdy pustynnych szejków z Algierii i Maroka ${ }^{100}$, tak dla dzisiejszej Bośni i Hercegowiny śmiertelnym zagrożeniem może okazać się obcy, ,importowany”, dogmatyczny islamizm.

\section{Bibliografia}

Alić A., Skocajić V., Understanding Bosnia, Part One, ISN Security Watch, February 26, 2009.

Babić M., Dramat tożsamości narodowej. Muzułmanie bośniaccy. https://www.researchgate.net/profile/Dr_Marko_Babic2/publication/235665983_Dramat_tozsamosci_narodowej_Muzulmanie_ bosniaccy/links/0912f5126cb71ce01d000000.pdf

Coalson R., Nikolić M., Radical Islamists Seek to Exploit Frustration in Bosnia, RFE/RL, March 1st, 2013.

Deliso Ch., The Coming Balkan Caliphate: The Threat of Radical Islam to Europe and the West, Westport, CT: Praeger Security International, 2007.

Djilas A., The Nation that Wasn't, [w:] N. Mousavizadeh (red.), The Black Book of Bosnia, HarperCollins Publishers, New York 1996.

Gibas-Krzak D., Bośnia i Hercegowina - upadek idei państwa multietnicznego na przełomie XX i XXI w. Zarys problemu, [w:] Bośnia i Hercegowina 15 lat po Dayton. Przeszłość - teraźniejszość - perspektywy, red. P. Chmielewski, S. L. Szczesio, Łódź 2011, s. 283-304.

Gibas-Krzak D., Terroryzm islamski na Bałkanach Zachodnich jako konsekwencja rozpadu Jugosławii w świetle badań naukowców batkańskich oraz zachodnich. Zarys problemu, [w:] Batkany Zachodnie między przeszłościa a przyszłościa, red. P. Chmielewski, S. L. Szczesio, Łódź 2013, s. $277-298$.

Hećimović E., Radical movements - a challenge for moderate Balkan-Islam? http://www.leviathan06. com/pdf_pool/publikationen/rel_exterm_vs_fried_beweg_05_radical_movements_moderate_ balkan_islam_e_hecimovic_17.pdf

Izetbegovic A., The Islamic Declaration: A Programme for the Islamization of Muslims and the Muslim Peoples, Sarajevo, Bosnia, 1990.

Kohlmann E., Al-Qaida's Jihad in Europe: The Afghan-Bosnian Network, Oxford, UK: Berg, 2004.

${ }_{99}^{9}$ M. R. Me no cal, Ozdoba świata. Jak muzułmanie, żydzi i chrześcijanie tworzyli kulturę tolerancji w średniowiecznej Hiszpanii, Wydawnictwo Uniwersytetu Jagiellońskiego, Kraków 2006.

${ }^{100}$ Wywiad z Piotrem Ibrahimem Kalwasem, polskim muzułmaninem mieszkającym w Egipcie, pisarzem, publicystą. Rozmawiali Grzegorz Lindenberg i Jan Wójcik z Euroislam.pl, https://euroislam.pl/boimysie-smierci-allaha-zamordowanego-przez-nowoczesnosc-cz-2/ 
Lebl, Leslie S., Islamism and Security in Bosnia-Herzegovina, Global Challenges, Didactic Press. Kindle Edition, miejsce wydania? 2015.

Mahmutćehajić R., The Denial of Bosnia, The Pennsylvania State University Press, 2000.

Martin R. C. (ed.), Encyclopedia of Islam and the Muslim World, New York 2004.

Schindler J. R., Unholy Terror: Bosnia, Al-Qa'ida, and the Rise of Global Jihad, St. Paul, MN: Zenith Press, 2007.

Skocajić V., Alić A., Understanding Bosnia, Part Four, ISN Security Watch, March 12, 2009.

Woehrel S., Bosnia and Herzegovina: Current Issues and U.S. Policy, Congressional Research Service, (CRS) Report R40479, Washington, DC: CRS, 24.01.2013.

\author{
Paweł Płaneta
}

\title{
Bosnia and Herzegovina at the crossroads Revitalization of Muslim identity or Islamization of the country?
}

Summary

By the outbreak of the civil war in the 1990s, traditional Bosnian Islam was moderate and liberal, however its nature underwent some deep changes especially under the influence of the Arab Mujahideen, who supported the Bosnian Muslims in the fighting with the Serbs, and - after the civil war - stayed in the country.

The author discusses possible variants of the situation in Bosnia and Herzegovina: either the latent conflict will continue, which may lead to new acts of violence and disintegration of the country, or the consolidated state will be able to rebuild social trust and political stabilization, and finally will successfully complete its integration with the European Union and NATO. Unfortunately, Bosnia and Herzegovina remains vulnerable to Islamic political-religious extremism. Probably the Bosnian Muslims, who are attached to the local tradition of moderate and progressive Islam, may reject radical slogans. One must remember, however, that when in the 1990s the intolerant ideas appeared in the Western Balkans, they were belittled. Soon it turned out that extremists from religiously oriented political parties quickly went from slogans and manifestations to violence. We must not underestimate the current situation, because the crisis in Bosnia and Herzegovina is particularly vulnerable to the impact of radical movements.

The situation is complicated by the fact that Bosnia and Herzegovina no longer functions only as a safe haven for Islamic radicals. The war in Syria, Iraq, international terrorism, economic and social crisis in the Muslim world have led to a horrendous migration/refugee crisis which has created the "gateway" to Europe for many Islamic fundamentalists in the whole region of the Western Balkans. That is why, according to many nationalists - in Bosnia, in the region, and in Europe - the days of Western civilization's final clash with Islam are coming. In Bosnia, the Orthodox population counts on Russia's leadership in the final victory over global jihad. An additional element on the geopolitical chessboard is Turkey, which is gaining greater power in the international arena and which strongly supports the reconstruction of the "Ottoman" identity in the Balkans.

Keywords: Bosnia and Herzegovina, Muslim identity, terrorism, international relations. 